\title{
Influence of grassland management on the abundance of the endophytic fungi Neotyphodium
}

\author{
Dissertation \\ zur Erlangung des Doktorgrades \\ der Fakultät für Agrarwissenschaften \\ der Georg-August-Universität Göttingen
}

vorgelegt von

Lana Dobrindt

geboren in Minsk (Weißrussland)

Göttingen, September 2011 



\section{7}

1. Referentin/Referent:

2. Korreferentin/Korreferent:

Tag der mündlichen Prüfung:
Prof. Dr. Stefan Vidal

Prof. Dr. Johannes Isselstein.

15.11.2011 
Für meinen Vater 


\section{Table of contents}

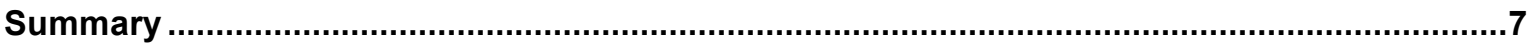

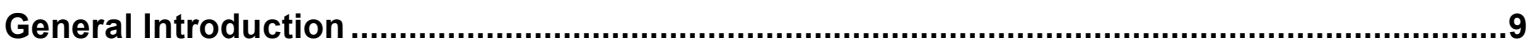

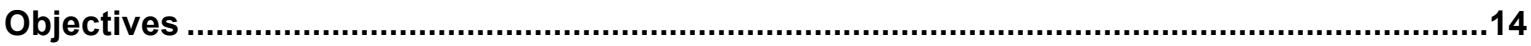

Chapter 1 Infected - not infected: Factors influencing the abundance of the endophyte Neotyphodium lolii in managed grasslands .........................................................................

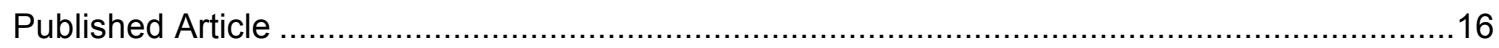

Chapter 2: Influence of grassland management on the abundance of the endophytic fungus

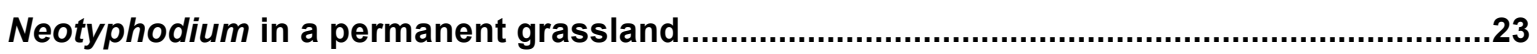

Introduction . 26 28

Chapter 3: Influence of grazer species and sward diversity on the abundance of the endophytic fungus Neotyphodium - does plant diversity matter? ..........................................46

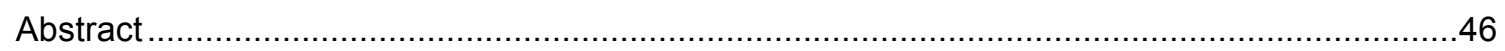

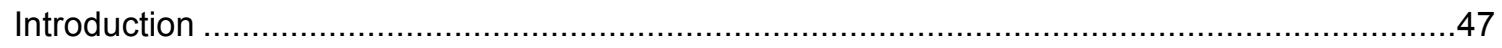

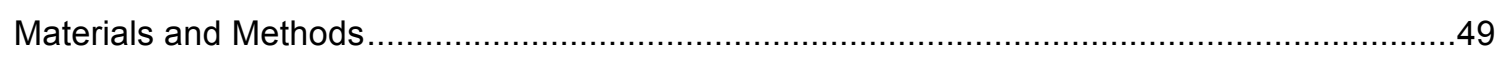

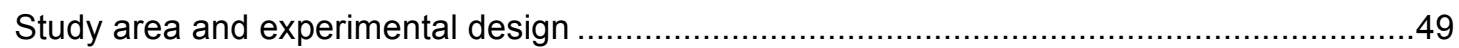

Forage selectivity and Jacobs' selection index...............................................................

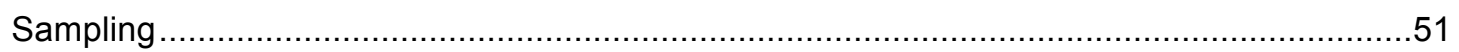

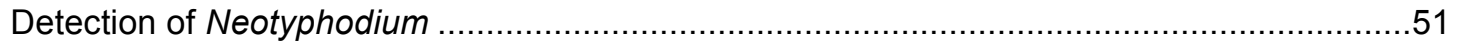

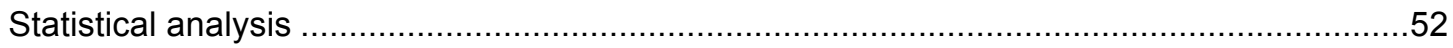

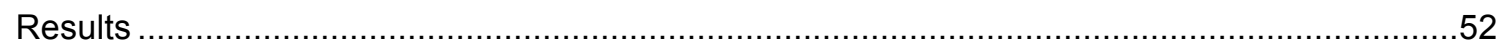

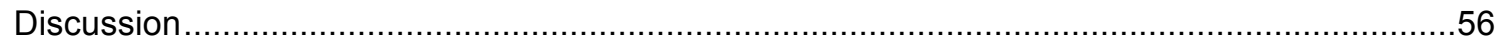

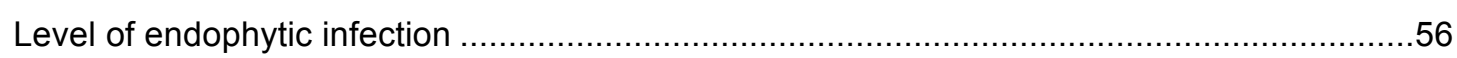

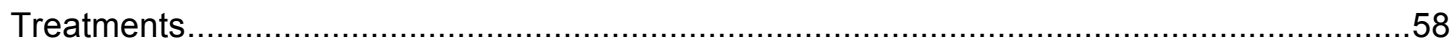




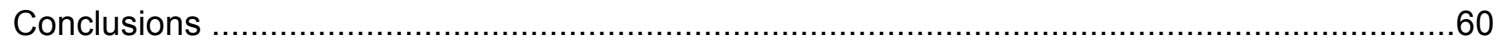

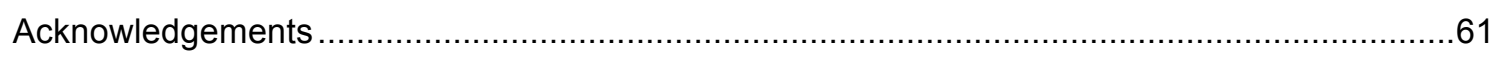

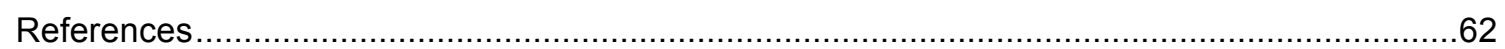

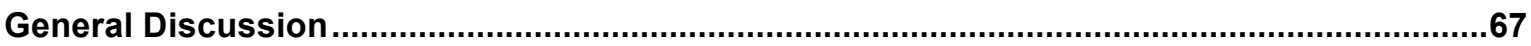

References cited in general introduction and discussion ................................................

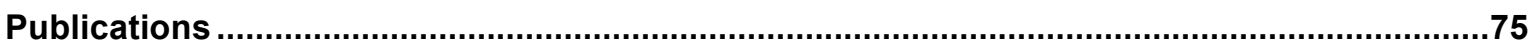

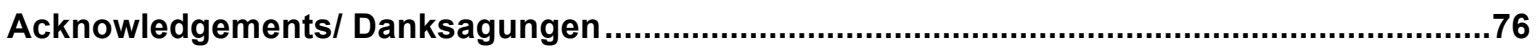

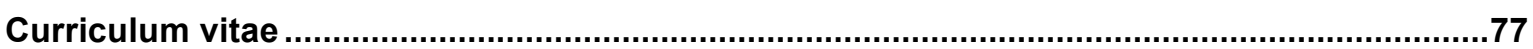

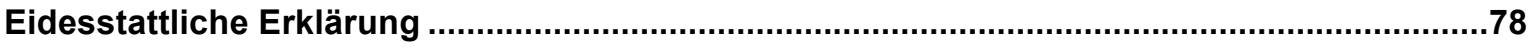




\section{Summary}

The endophytic fungus Neotyphodium spec. Glenn, Bacon and Hanlin is common in many temperate grass species. This fungus is known to enhance the resistance of its host to adverse environmental conditions and to promote its growth. In addition, Neotyphodium spec. produces a wide range of alkaloids and can therefore be toxic to livestock. Many studies dealing with this topic were conducted in the intensively managed grasslands of the USA and New Zealand. However, we still lack knowledge about the abundance of this fungus in cultivated grasslands in Europe under different management regimes. This information could contribute to a better understanding of the fungal ecology and help to assess the risk of toxicoses in European grasslands. Hence, the objective of this study was to investigate the impact of grassland management on the incidence of Neotyphodium spec. in different grass species.

1) In the rural district of Northeim (central Germany) the impact of land use intensity and type of grassland use on the incidence of Neotyphodium lolii (Latch, Christensen and Samuels), Glenn, Bacon and Hanlin in perennial ryegrass (Lolium perenne L.) was investigated in 90 managed grasslands.

- The mean infection rate of L. perenne with $N$. lolii was low.

- The intensity of land use (extensive, intermediate, intensive) and the type of grassland (pasture, mown pasture, meadow) had no influence on the abundance of the fungus.

- Geology significantly influenced the incidence of $N$. lolii: L. perenne plants collected from sites with limestone bedrock had higher infection rates than plants from other soils.

2) The influence of fertilization, cutting frequency and sward composition on the abundance of Neotyphodium spec. in four grass species was tested in an experimental grassland in the Solling Uplands, central Germany.

- Cutting frequency and sward composition did not influence the incidence of Neotyphodium spec. 
- Fertilization significantly increased the infection rate of the tested grass species compared to non-fertilized plots.

3) It was tested how grazing of cattle, sheep and co-grazing of cattle and sheep under different diversity regimes (high and low sward diversity) influences the abundance of Neotyphodium spec. in L. perenne and Festuca pratensis Huds. (meadow fescue). This investigation was carried out in an experimental pasture in the Solling Uplands, central Germany.

- In the high diversity treatment grazing and co-grazing of cattle and sheep had no influence on the abundance of the fungus in both grass species.

- In the low diversity treatment the incidence of Neotyphodium unicatum (Gams, Petrini and Schmidt) Glenn, Bacon, Price and Hanlin in F. pratensis was significantly higher in plots co-grazed by cattle and sheep compared to plots grazed by sheep only. In contrast, there was no difference in the abundance of $N$. Iolii in $L$. perenne between the grazing treatments. 


\section{General Introduction}

Grasslands cover about 3500 million ha worldwide, half of them being indicated as natural grasslands (Carlier et al., 2009). Grasses inhabit most ecoregions of the Earth such as savannas, scrublands, coastal plains, mountain regions, tundra and deserts. They can be found in all continents including the Antarctic. Grassland covers 230 million ha in Europe with 64 million ha being agriculturally used as permanent grassland. In Germany, agriculturally utilized permanent grassland covers about five million ha, which is $30 \%$ of the total arable land of this country (Eurostat).

Grassland fulfills many different functions and is utilized in numerous ways (reviewed in Carlier et al., 2009). It provides forage to livestock and wild herbivores, prevents erosion, increases the water holding capacity of the soil and serves as filter for pesticides and nutrients. In addition, grassland sequesters carbon and acts therefore as a carbon sink reducing the amount of atmospheric $\mathrm{CO}_{2}$. Grasses can also be utilized as energy crops and for the production of renewable fuels. Moreover, grasses are well adapted to tolerate disturbances and are therefore used as turf for football pitches, golf courses and other sport fields as well as for parks and lawns. An important function of grasslands is their contribution to the biodiversity of rural landscapes (Isselstein, 2005). Extensively managed grasslands consist of a high number of different plant species and provide an essential habitat for many vertebrate and invertebrate animal species.

The cool-season grasses of temperate regions are often infected with fungal endophytes of the genus Neotyphodium Glenn, Bacon and Hanlin (Leuchtmann, 1993; Zabalgogeazcoa et al., 2003). This genus belongs to the family Claviciptaceae and the division of Ascomycota. Some species of this family such as ergot (Claviceps purpurea (Fr.) Tul.) are obligate parasites of grasses and sedges (White, 1997). In contrast, the Neotyphodium-grass symbiosis is considered as mutualistic (Clay, 1988). A mutualism is defined as an interspecific interaction between individuals in which each participant benefits from the association (Thompson, 1994). In a mutualistic association both partners exchange goods or services resulting in a relative increase in the fitness of each partner. The mutualistic interaction can be either obligate or facultative. In a 
facultative association the survival of a partner is independent of the interaction whereas in an obligate association, a partner can not survive without the other (Wilkinson and Schardl, 1997).

Applied to the Neotyphodium endophyte association, the interaction is obligate for the fungus as it depends on the supply of nutrients, water and shelter from its host. From the plant's perspective, the interaction is facultative as the plant is able to survive without the fungus but benefits from the association (Breen, 1994). The term "endophyte" itself has been controversial for a long period of time (Wennström, 1994). Wilson (1995) defined endophytes as microorganisms inhabiting the plant's tissue for at least a period of their life cycle without causing any visible symptoms of disease. The endophytic fungi of the genus Neotyphodium systemically colonize the aboveground parts of their host including leaf sheaths, leaf blades, the pseudostem, the inflorescence and the plant's seeds. Neotyphodium endophytes do not produce spores and are transmitted vertically via infected seeds of or through tillering of the host plant (Clay and Schardl, 2002). Neotyphodium endophytes have been shown to benefit their grass host in many different ways one them being the increased resistance to adverse environmental conditions (Malinowski and Belesky, 2000). For instance, endophytes have been shown to enhance the performance of grasses under drought stress (Arachevaleta et al., 1989) with different mechanisms involved. These mechanisms include (reviewed in Malinowski and Belesky, 2000):

1) Drought avoidance through increased root hair lengths and a decreased root diameter thus increasing the absorptive surface for water uptake.

2) Drought tolerance through accumulation of water-soluble sugars, fungal metabolites and amino acids increasing the osmotic pressure and reducing the evapotranspiration of the plant.

3) Improved water use efficiency through faster stomatal closing and reduced transpiration rate in comparison to uninfected plants.

Moreover, endophytic fungi have been shown to increase the resistance of infected grasses to salinity stress (Sabzalian and Mirlohi, 2010) and to improve the uptake of phosphorous, potassium and other nutrients (Malinowski and Belesky, 2006; Khayamim et al., 2010).

Apart from enhanced performance under abiotic stresses endophytic fungi are also able to enhance the tillering, growth and germination rate of their hosts (Latch 
et al., 1985; Joost, 1995). Also, Jensen and Roulund (2004) have found a higher infection rate of perennial ryegrass (Lolium perenne L.) with Neotyphodium Iolii (Latch, Christensen and Samuels), Glenn, Bacon and Hanlin in areas heavily used by public compared to undisturbed grass areas in Denmark. These results indicate that Neotyphodium is able to increase its host resistance to anthropogenic stress. Another important benefit provided by the fungus is its ability to produce a wide range of bioprotective alkaloids active against nematodes, insects, birds and mammals (Breen, 1994; Conover and Messmer, 1996; Bush et al., 1997). While peramine is a feeding deterrent to insects, lolines act as metabolic toxins and as feeding deterrents while expressing a very low activity against mammals (Bush et al., 1997). For instance, endophyte infected perennial ryegrass produces peramine and is therefore resistant against the Argentine stem weevil (Listronotus bonariensis Kuschel), which causes severe stand losses in endophyte free ryegrass stands in New Zealand (Prestidge et al., 1982). Ergot alkaloids produced by endophyte-infected grasses express a strong activity against mammals and can be therefore detrimental to grazing livestock. Neotyphodium coenophialum (Morgan-Jones and Gams) Glenn, Bacon and Hanlin, the endophytic fungus of tall fescue (Festuca arundinacea Schreb.) produces ergovaline, which causes a disease called "fescue toxicosis" (Bacon et al., 1977). Cattle suffering from fescue toxicosis have a reduced weight gain, lameness caused by vasoconstriction and an elevated body temperature (Belesky and Bacon, 2009). The detection of the link between fescue toxicosis and the presence of Neotyphodium in tall fescue stimulated a great deal of research in this field (Hoveland, 1997) due to the severe economic losses related to this disease. Similarly, Fletcher and Harvey (1981) discovered a link between "ryegrass staggers", a nervous disorder in livestock and Iolitrem B produced by the endophyte of perennial ryegrass, Neotyphodium Iolii. $\mathrm{N}$. Iolii produces ergovaline as well, but the level of lolitrem B found in infected ryegrass is significantly higher. Therefore, animals having fed infected ryegrass first express symptoms of ryegrass staggers before showing symptoms of fescue toxicosis (Hovermale and Craig, 2001). It was estimated that the beef cattle industry of the United States suffered more than $\$ 600$ million losses per year due to fescue toxicosis whereas the losses to the New Zealand livestock industry were $\$ 40$ million per year at the end of the $20^{\text {th }}$ century (Joost, 1995). 
Problems with livestock toxicoses are not common in Europe (Zabalgogeazcoa and Bony, 2008) for different reasons. One of them is the composition of the swards with European swards being more diverse than those found in the United States or New Zealand. Another reason could be the lower grazing pressure of livestock in European pastures as grazing pressure has been shown to increase the level of endophytic infection (Gwinn et al., 1998; Jensen and Roulund, 2004). Several studies have shown that livestock and wild mammalian herbivores are able to discriminate between infected and uninfected grasses (Gwinn et al, 1998; Koh and Hik, 2007). Therefore, infected grasses benefit from this selective advantage, which leads to an elevated infection rate of the fungus.

In Europe, an increase in land use intensity rates along with a loss of sward diversity was observed since the 1960 (e.g. Klimek et al., 2007; Weibull et al., 2003). Hence, toxicosis of livestock could also occur in intensively managed European pastures. On the other hand, several studies have shown that the grassendophyte association is not always mutualistic and can become antagonistic depending on environmental conditions, the availability of nutrients and hostgenotype interactions (Saikkonen et al., 1998; Ahlholm et al., 2002; Hesse et al., 2004). In addition, Saari et al. (2010) found a reduced incidence of endophytic fungi in meadow fescue (Festuca pratensis Huds.) grazed by cattle in comparison to ungrazed control plots in a field trial in Finland. These contrasting results call for additional studies.

The objective of this work was to find out how different grassland management regimes influence the abundance of endophytic fungi in central Germany to be able to assess the risk of livestock toxicoses deriving from these practices. We hypothesize that more intensively managed grassland should show a higher level of endophytic infection. Management practices, such as fertilization, heavy grazing and frequent mowing can be stressful to grasses and should therefore promote higher rates of endophytic infection.

The first study was conducted in agriculturally used grasslands including meadows, mown pastures and pastures. To analyze the pattern of endophytic distribution, we surveyed the impact of different environmental variables like botanical composition of the sward, altitude, geology and soil composition on the abundance of Neotyphodium Iolii in L. perenne. The second study was conducted in an experimental grassland and investigates the impact of mowing, fertilizer 
application and sward composition on the abundance of Neotyphodium in different grass species in a experimental grassland. In the third study, we examined how grazing of different livestock species (cattle, sheep, and co-grazing of cattle and sheep) influences the abundance of Neotyphodium at different sward diversities (high or low diversity). 


\section{Objectives}

The aim of this work was to investigate the impact of grassland management on the abundance of the endophytic fungus Neotyphodium in different grass species. Additionally, it was intended to determine the general level of endophytic infection in central Germany and to find out more about environmental factors influencing the incidence of the fungus.

1. The abundance of Neotyphodium Iolii in Lolium perenne in different types of grassland (meadows, mown pastures, pastures) at varying land use intensities (extensive, intermediate, intensive) was analyzed in 90 agriculturally utilized grasslands in the rural district of Northeim, central Germany.

2. The influence of different environmental variables such as altitude, composition of the soil and geology on the incidence of Neotyphodium was surveyed in order to analyze the pattern of endophytic distribution. This investigation was carried out in the same area.

3. The impact of mowing frequency, sward diversity and fertilizer application on the abundance of Neotyphodium in four grass species was studied in an experimental permanent grassland in the Solling Uplands, central Germany.

4. It was tested how grazing of different livestock species (sheep, cattle, cograzing of cattle and sheep) under varying sward diversities (high or low diversity) influences infection rate of Neotyphodium in two grass species. This study was conducted in an experimental pasture in the Solling Uplands. 


\section{Chapter 1}

Infected - not infected: Factors influencing the abundance of the endophyte Neotyphodium lolii in managed grasslands
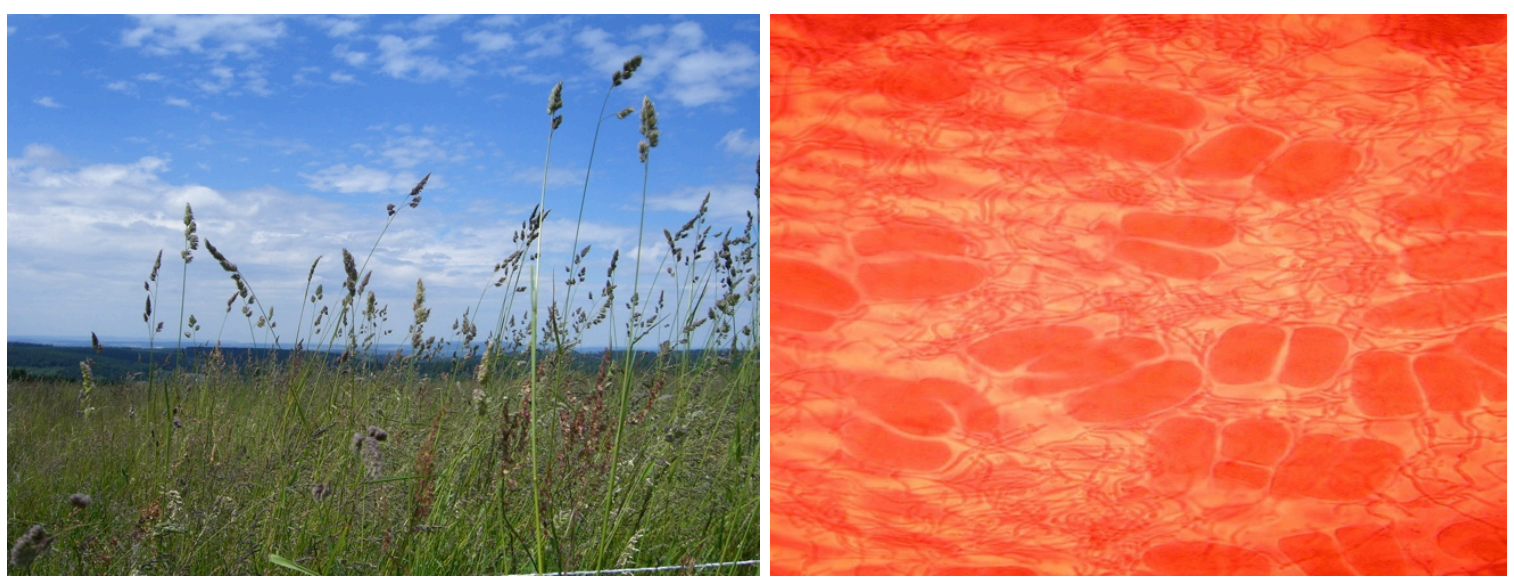

Authors: Lana Dobrindt, Hans-Georg Stroh, Johannes Isselstein, Stefan Vidal*

${ }^{*}$ Corresponding author

This chapter is published in:

Agriculture, Ecosystems and Environment 175 (2013) 54-59

Please access by DOI: 10.1016/j.agee.2013.05.010

(C) 2013 Elsevier B.V. 


\title{
Agriculture, Ecosystems and Environment
}

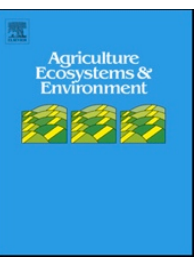

journal homepage: www.elsevier.com/locate/agee

\section{Infected-not infected: Factors influencing the abundance of the endophyte Neotyphodium lolii in managed grasslands}

\author{
Lana Dobrindt ${ }^{\mathrm{a}}$, Hans-Georg Stroh ${ }^{\mathrm{b}}$, Johannes Isselstein ${ }^{\mathrm{b}}$, Stefan Vidal ${ }^{\mathrm{a}, *}$ \\ ${ }^{a}$ Georg-August University Göttingen, Department of Crop Science, Agricultural Entomology, Grisebachstrasse 6, 37077 Göttingen, Germany ${ }^{\text {b }}$ Georg-August \\ University Göttingen, Department of Crop Science, Grassland Science, Von-Siebold-Strasse 8, 37077 Göttingen, Germany \\ CrossMark
}

Article info

Article history:

Received 15 December 2011

Received in revised form 21

December 2012 Accepted 13 May

2013

Available online 10 June 2013

Keywords:

Endophytic fungus

Grassland management

Lolium perenne

Drought stress

Environmental stress

Soil type

\begin{abstract}
Temperate grasses are infected with endophytic fungi of the genus Neotyphodium. These fungi asymptomatically live inside the plant's tissue enhancing resistance of their hosts to herbivores and abiotic stresses. Perennial ryegrass (Lolium perenne), infected with Neotyphodium lolii can be detrimental to grazing livestock causing a neural disease. This study aimed at determining the impact of grassland management on fungal incidence. In a rural district of Central Germany 90 sites differing in land use intensity (extensive, intermediate and intensive) and grassland use (pastures, mown pastures, and meadows) were investigated for the presence of N. lolii. Infections were detected in $41 \%$ of the sites sampled, but overall infection rates were low $(5.8 \pm 9.2 \%)$. Neither the intensity of land use nor the type of grassland influenced endophytic incidences. In contrast, the geology of the sampled sites had a significant impact on the incidence of N. lolii. Grass tillers collected from limestone sites showed significantly higher infection rates than from other soils. We hypothesize that the low field capacity and high amount of potassium on limestone sites favored the survival of infected grasses under drought stress. Therefore, geology should be taken into account when considering management strategies for this endophytic fungus.
\end{abstract}

(C) 2013 Elsevier B.V. All rights reserved.

\section{Introduction}

Perennial ryegrass (Lolium perenne L.) is the most important forage and turf grass species in Europe (Zabalgogeazcoa and Bony, 2008) because of its high productivity and feeding value and its high trampling tolerance. It is often infected with the endophytic fungus Neotyphodium lolii (Latch, Christensen and Samuels), Glenn, Bacon and Hanlin (Lewis et al., 1997). Endophytes are microorganisms living inside the plant's tissue without causing any visible symptoms of disease (Wilson, 1995). Specialized endophytes of the genus Neotyphodium are common in many temperate grass species (Leuchtmann, 1993; Saikkonen et al., 2000; Zabalgogeazcoa et al., 2003). They infect the grass shoots systemically and are vertically transmitted via their host's seeds. The fungus-host association is often considered as mutualistic (Clay, 1988, Breen, 1994). The plant provides the fungus with nutrients, water and shelter and takes care of its spread whereas the fungus enhances the resistance of its host to biotic and abiotic stresses (Clay, 1988; Breen, 1994; Malinowski and Belesky, 2000). Neotyphodium produces a range of bioprotective alkaloids (Bush et al., 1997) that are not only detrimental to insects and nematodes but also toxic to grazing livestock. The alkaloids of $\mathrm{N}$. lolii in ryegrass can cause a nervous disorder called

\footnotetext{
* Corresponding author. Tel.: +49055139 9744; fax: +49055139 12105. E-mail address: svidal@gwdg.de (S. Vidal).
}

"ryegrass staggers" in horses, cattle and sheep, whereas the toxins produced by Neotyphodium coenophialum (Morgan-Jones and Gams) Glenn, Bacon and Hanlin in tall fescue (Festuca arundinacea Schreber) can cause the fescue toxicosis syndrome in livestock (Bacon et al., 1977; Fletcher and Harvey, 1981). Resistance to abiotic stresses includes drought tolerance and drought avoidance, an increased uptake of phosphorous and other nutrients as well as higher tolerance to salinity stress (Malinowski and Belesky, 2000; Sabzalian and Mirlohi, 2010).

However, there is evidence that the positive effects of endophytes are more pronounced in nutrient-rich, managed grasslands than in natural grassland ecosystems (Faeth and Fagan, 2002; Saikkonen et al., 2006, Saikkonen et al., 2010). Hence, the grassendophyte association can vary from mutualistic to antagonistic depending on host-genotype interactions, environmental conditions and nutrient availability (Saikkonen et al., 1998; Ahlholm et al., 2002; Hesse et al., 2004).

Although Europe is the original habitat of many Neotyphodium endophytes, most field studies were conducted in the USA and New Zealand where intoxication of livestock causes the severe problems mentioned above. This might be attributed to the high grazing pressure of livestock and the less diverse botanical composition of the sward (Malinowski and Belesky, 2006). Gwinn et al. (1998) showed that the incidence of $\mathrm{N}$. coenophialum in tall fescue stands was positively correlated with the grazing pressure of livestock and increased over a period of a few years. Reports of livestock toxicosis 
from Europe are rare (Zabalgogeazcoa and Bony, 2008). Nevertheless, some evidence from Europe exist that grazing increases the abundance of L. perenne infected with N. lolii in semi-natural grasslands in Denmark (Jensen and Roulund, 2004). In contrast, Saari et al. (2010) found a lower abundance of Neotyphodium uncinatum (Gams, Petrini \& Schmidt) Glenn, Bacon, Price \& Hanlin in grazed meadow fescue (Festuca pratensis Huds.) in Finland. These contrasting results call for additional studies explaining the pattern of endophyte abundance in relation to abiotic and biotic parameters. We are not aware of any studies investigating the intensity of grassland management and use on the abundance of N. lolii in Central Europe.

Along with increasing land use intensity a loss of grassland diversity all over Europe was observed since the 1960s (e.g. Dierschke and Briemle, 2002; Hodgson et al., 2005; Klimek et al., 2007; Weibull et al., 2003). Therefore, it is important to find out more about the influence of management intensity on endophytic abundance in order to assess the risk of livestock intoxication in managed European grasslands. The scope of this study is to determine the incidence of $\mathrm{N}$. lolii in agriculturally used grasslands and to investigate the influence of grassland management on the abundance of the endophytic fungus $\mathrm{N}$. lolii in grasslands of central Germany. Based on previous studies (Gwinn et al., 1998; Jensen and Roulund, 2004), we hypothesize that more intensively managed grassland should experience higher incidences of N. lolii. Heavy grazing was shown to increase the level of endophytic infection (Gwinn et al., 1998), which is more likely to occur in intensively managed grasslands. Bazely et al. (1997) hypothesized that animals might be selective in their feeding behavior due to the bitter taste of alkaloids produced by the fungus. From this it follows that a high grazing pressure should result in a high incidence of the fungus. Therefore, heavy grazing in intensively managed grasslands might select for higher levels of endophytic infection compared to the extensively managed grasslands. We also hypothesize that the differently used grasslands like pastures, mown pastures, and meadows should differ in their abundance of N. lolii due to the selective feeding of grazing livestock. Jensen and Roulund (2004) have shown that endophytes enhance the resistance of their hosts to different types of stresses, such as anthropogenic or environmental stress. As frequent mowing might also represent a stress factor we hypothesize that frequently mown grasslands should experience higher infection rates with $\mathrm{N}$. lolii than rarely mown ones. This is in line with the finding of Spyreas et al. (2001) who found a higher incidence of $\mathrm{N}$. coenophialum in mown plots in comparison to unmown plots. To analyze the pattern of endophytic distribution, we surveyed the impact of other environmental variables like botanical composition of the sward, altitude, geology and soil composition on the rate of endophytic infection.

\section{Materials and methods}

\subsection{Sampling}

In August/September 2008 and 2009 L. perenne tillers were collected from 90 managed grassland fields in the rural district of Northeim (Lower Saxony, Germany), located in the center of Germany (Fig. 1). The sampling locations were subdivided into three types (pastures, mown pastures and meadows) with three levels of land use intensity (intensive, intermediate and extensive). Land use intensities were derived from categories proposed by Bockholdt et al. (1996), but were focused here on the amount of nitrogen supply and defoliation frequency only to get a scheme for classification. Each land use type and intensity level were replicated 10 times (Fig. 2). The pastures and mown pastures were grazed by cattle. In 2008 five plants per plot and 2009 ten plants of $\mathrm{L}$. perenne

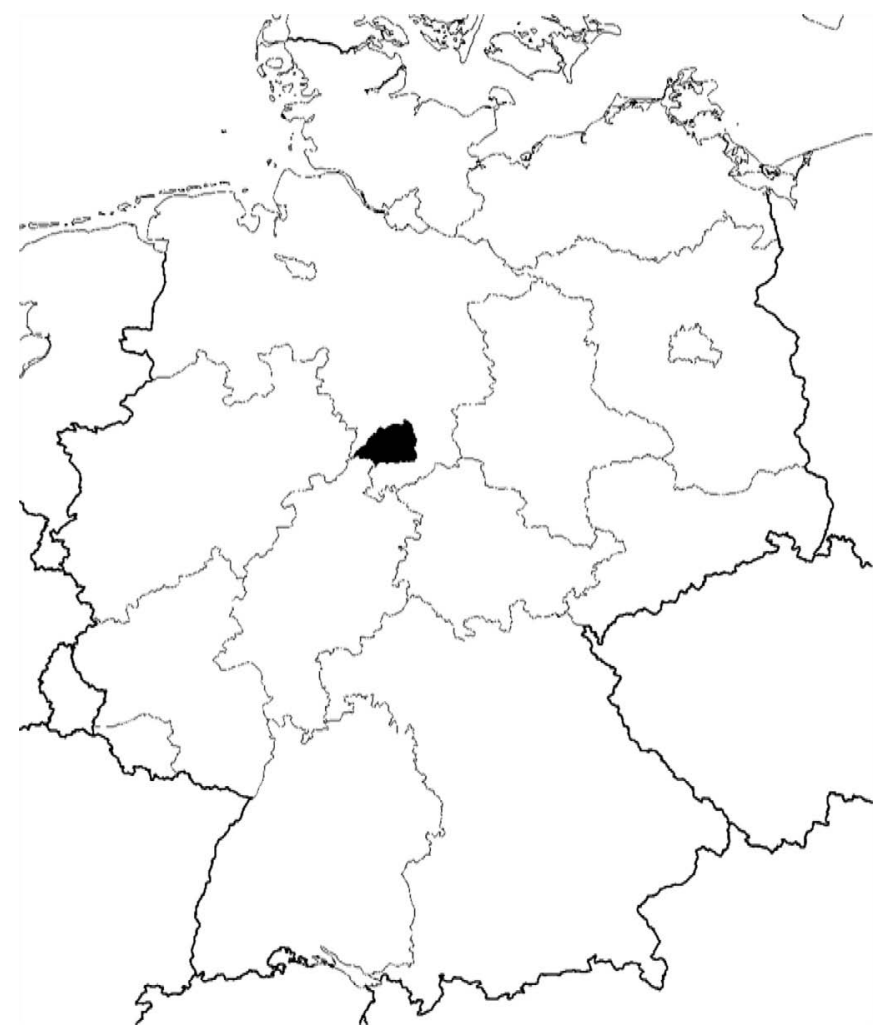

Fig. 1. Location of the district of Northeim, Lower Saxony, Central Germany, where the samples had been taken.

were sampled. One plot (grassland) represented the unit of replication, resulting in 90 replicates in total. Due to a low rate of infection found in 2008, the sample size was increased in 2009 reducing the variance and improving the statistical analysis whereas the number of replicates remained the same as in 2008. The collected grass tillers were randomly chosen from different parts of the grasslands with a minimum distance of $5 \mathrm{~m}$. Following cutting, the plants were transported to the laboratory in a cool box, where they were frozen in nylon bags at $-20^{\circ} \mathrm{C}$ until further investigation.

\subsection{Measurement of type, intensity and other factors}

Different parameters with regard to plot specific characteristics and management practices were conducted from previous studies at the same fields (Stroh et al., 2009). Topographic site attributes were estimated from field measures (exposition, inclination) or derived from GPS-data. Data on parent material (geology) are based on information of local geological maps. Soil types were determined by visual and haptical characteristics of the field samples. Reaction ( $\mathrm{pH}$-value) and nutrient content (CAL-methode) were measured from soil samples.

Meteorological data were derived from the "Wetterstation Göttingen" (www.wetterstation-goettingen.de) located in the rural

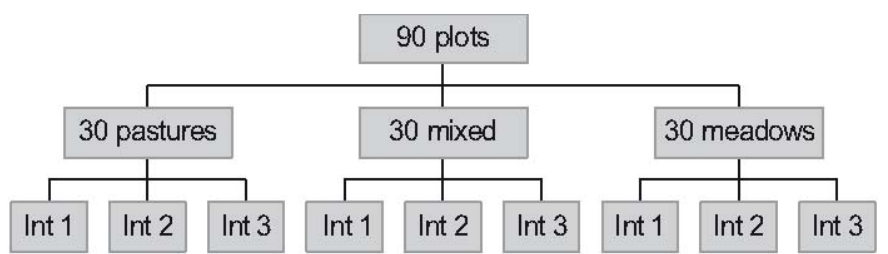

Fig. 2. Scheme of collection site selection. Each intensity level (Int) was replicated ten times, the label "mixed" refers to mown pastures. 
district of Northeim. The mean annual temperature for the last 30 years was $8.7^{\circ} \mathrm{C}$ with an annual precipitation of $644.9 \mathrm{~mm}$. In 2008 the mean annual temperature was $9.8{ }^{\circ} \mathrm{C}$ with an annual precipitation of 561.3. According to the "Wetterstation Göttingen", the year 2008 was warmer (more than $1{ }^{\circ} \mathrm{C}$ ) and dryer (less than 90\%) than the mean reference values of the last 30 years. In the year 2009, the mean annual temperature was $9.3^{\circ} \mathrm{C}$ and the annual precipitation was $670.2 \mathrm{~mm}$, which is in line with the mean reference values.

Land use practice, farm specific nitrogen input, cutting regimes, grazing intensity, and some other management parameters such as use of pesticides, frequency of reseeding and oversowing, age of grass sward, were compiled using farmers' records. Values for nitrogen were converted into quantitative values $\left(\mathrm{kg} \mathrm{N} \mathrm{ha}^{-1} \mathrm{yr}^{-1}\right)$, using standardized tables of N-contents (KTBL 2005, Düngeverordnung). For further details see also the supplemental material.

\subsection{Detection of N. lolii}

The sampled plants were analyzed for the presence of $\mathrm{N}$. lolii using the ELISA-based Phytoscreen field tiller kits obtained from Agrinostics, Watkinsville, USA. The kits were developed for the detection of the endophytic fungus in F. arundinacea and L. perenne. Koh et al. (2006) showed that they are suitable for the detection of Neotyphodium in largescale studies. Hiatt et al., 1999 and Dombrowski et al. (2006) have also shown that this test favorably compares to a microscopic analysis as well as to a PCR-based method. Cross-sections of L. perenne tillers were placed on an immunoblot membrane and incubated over night allowing fungal proteins to bind on its surface. Subsequently antibodies specific to Neotyphodium spec., an enzyme, and a chromogen solution were added. Infected tillers developed a pink imprint whereas the imprint of uninfected tillers remained uncolored.

\subsection{Statistical analysis}

The data were analyzed with a general linear model (GLM) with binomial distribution and logit link function using R version 2.9.2 (R Development Core Team, 2009). Endophytic infection was used as the dependent variable and type of grassland, intensity of land use, abundance of Neotyphodium in the sward, geology, altitude, exposition, topography, inclination, soil contents of potas- sium, magnesium, nitrogen and phosphorus, soil $\mathrm{pH}$, and plant species richness ( $\alpha$-diversity) as explanatory variables. To correct for overdispersion (residual deviance/degrees of freedom $>1$ ) the standard errors were multiplied by the square root of the disper- sion parameter $\varphi$ estimated as 1.71, using a quasi-GLM. Backward model selection was performed using the F-test. Linear contrasts from the R-package MASS (Venables and Ripley, 2002) were used to test for differences between treatments and factor levels. For model validation residuals were plotted against predicted values and analyzed graphically. Because of the heteroscedasticity of variances for a linear regression of the potassium data, this variable was logtransformed and analyzed with a linear model using potassium as the dependent variable and geology as a grouping variable.

\section{Results}

Being an important agronomic turf and forage grass L. perenne was the most abundant grass species in management grasslands of the region. From relevés sampled for biodiversity studies (Stroh et al., 2009) in the same fields the cover of $\mathrm{L}$. perenne ranged from $0.2 \%$ to $70 \%$, with an average of $22.6 \pm 19.1 \%$ (mean \pm SD). Two plots had no L. perenne and were therefore excluded from further analysis. We were able to identify infections of $\mathrm{N}$. lolii in only 36 out of the 88 plots sampled, and the mean rate of infection was $5.8 \pm 9.2 \%$ (SD). The percentage of infected plants in all sampled grasslands
Table 1

Effects of geology, type of grassland and land use intensity on the infection rate of perennial ryegrass with Neotyphodium lolii.

\begin{tabular}{lcccr} 
Factor & df & Deviance & F value & P level \\
\hline Geology & 4 & 157.34 & 4.8139 & $0.0016^{* *}$ \\
Type & 2 & 131.64 & 1.6028 & 0.2078 \\
Intensity & 2 & 128.69 & 0.6811 & 0.5090
\end{tabular}

Data were analyzed using the general linear model with binomial distribution and the F-test for backward model selection. $\quad{ }^{* *}$ Significance code: 0.001.

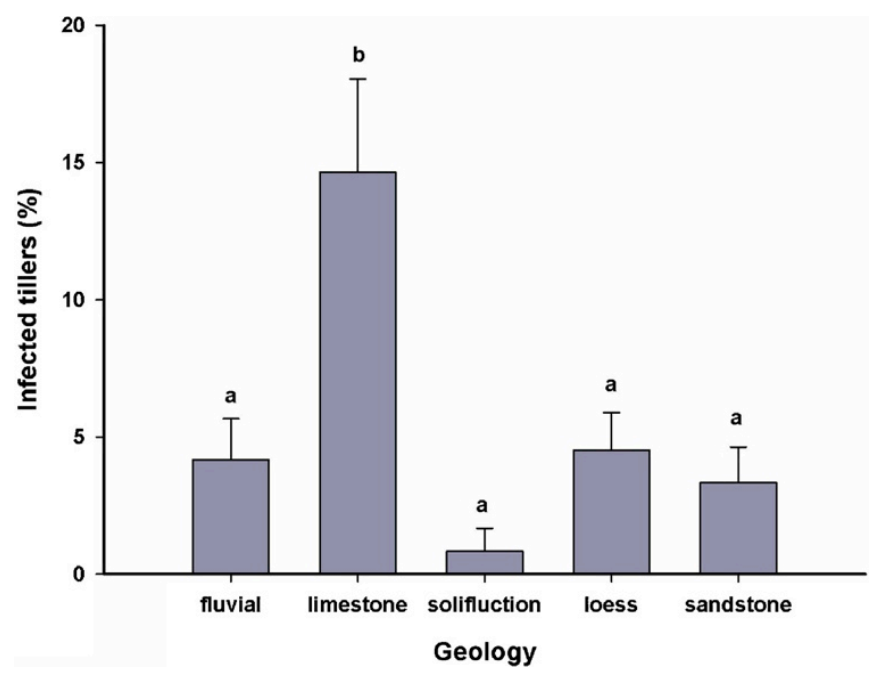

Fig. 3. Percentage of L. perenne tillers (mean + SE) infected with N. lolii depending on the geology of the collection sites. Letters above columns indicate significance of difference according to binomial GLM $(\mathrm{P}<0.05)$.

ranged from $6.6 \%$ to $40 \%$. Only $13.6 \%$ of the habitats had infection rates above $20 \%$ while $79.5 \%$ of the grasses had infection rates below $13 \%$.

Statistical analysis revealed that the impact of management factors for $\mathrm{N}$. lolii abundance was very low. The three levels of land use intensity (extensive, intermediate, intensive) had no significant influence on the abundance of N. lolii (Table 1). Also, the three types of grassland (pastures, mown pastures and meadows) did not significantly differ in their incidence of the endophytic fungus.

In contrast, we found a significant impact of parent material on the abundance of $\mathrm{N}$. lolii at the sampled sites. Grass samples taken from limestone showed the highest infection rates (Fig. 3), whereas samples from other bedrock materials were significantly less infected with the endophytic fungus. Also a significantly higher potassium level was found in these locations compared to soils developed from sandstone or loess substrates (Fig. 4.). Along with the limestone substrate a higher mean $\mathrm{pH}-$ value was found in those samples during further analyses (Table 2).

If tested alone, there was a significant influence of potassium (SE = 0.0117, $\mathrm{df}=1, \mathrm{t}$-value $=3.026, \mathrm{P}=0.00327)$ and $\mathrm{pH}(\mathrm{SE}=0.1730, \mathrm{df}=1, \mathrm{t}-$ value $=2.310, \mathrm{P}=0.0233$ ) on the endophytic infection. Potassium had a stronger impact on the abundance of $\mathrm{N}$. lolii than the $\mathrm{pH}$-value: If potassium content and $\mathrm{pH}$-value were

Table 2

$\mathrm{pH}$-values and sample size of different collection according to geology.

\begin{tabular}{lcc} 
Geology & pH $($ mean \pm SD) & Sample size $(\mathrm{n})$ \\
\hline Fluvial soil & $5.32 \pm 0.91$ & 24 \\
Limestone & $6.26 \pm 0.74$ & 16 \\
Solifluction soil & $5.19 \pm 0.86$ & 8 \\
Loess & $5.38 \pm 0.96$ & 28 \\
Sandstone & $4.91 \pm 0.60$ & 12
\end{tabular}




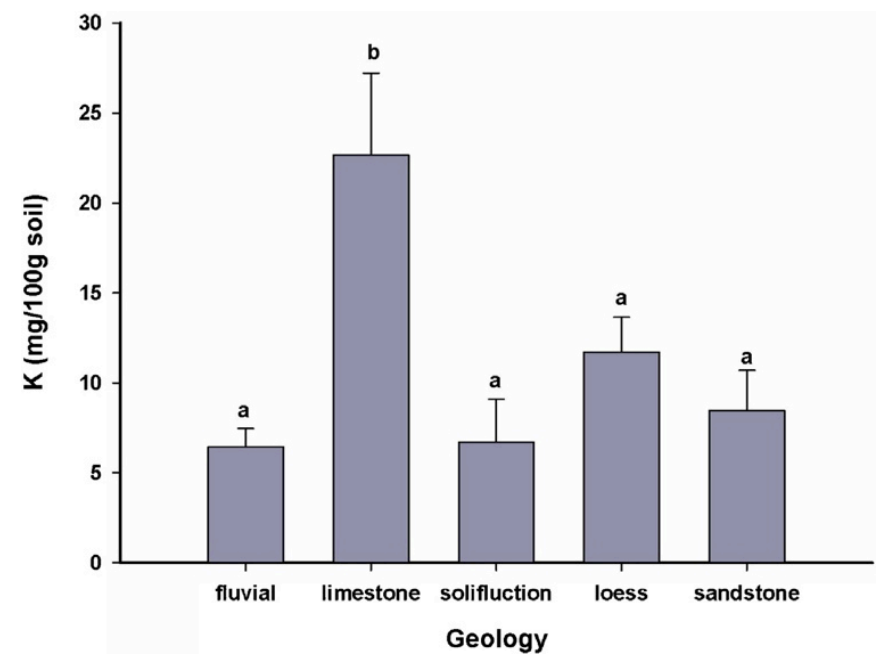

Fig. 4. Potassium content in the soil (mean $+\mathrm{SE})$ grouped by geology of the collection sites. Letters above columns indicate significance of difference according to LM $(\mathrm{P}<0.05)$.

modeled together only the content of potassium was significant (SE $=$ $0.01299, \mathrm{df}=1, \mathrm{t}$-value $=2.204, \mathrm{P}=0.0303$ ). As both parameters are related to the substrate they were not significant during the model selection. Other explanatory variables tested, such as the abundance of $\mathrm{L}$. perenne in the sward, altitude, exposition, topography, inclina- tion, content of magnesium, nitrogen and phosphorus, and the $\alpha$-diversity did not significantly influence the abundance of $\mathrm{N}$. lolii (Table 3 ).

\section{Discussion}

Contrary to our hypothesis, neither land use intensity nor the type of grassland significantly influenced the abundance of N. lolii in L. perenne. In this study, only geology of the sampled sites had an impact on the abundance of the endophytic fungus. L. perenne plants sampled from sites with limestone as parent material had significantly higher levels of infection than those collected from other soils. Therefore, to our knowledge this is the first study in Europe showing an effect of geology on the incidence of Neotyphodium spp. Possible explanations for the findings mentioned above are discussed in the following section.

\subsection{Level of endophytic infection}

The endophytic fungus N. lolii was not very abundant in the study area, although the level of infestation showed much variation. Less than half of the sampled plots were infected and the mean level of infestation was low. Our findings are consistent with Oldenburg (1997) who investigated several regions of Germany including Lower Saxony for the presence of N. lolii in L. perenne. She

\section{Table 3}

Mean, standard deviation (SD) and range of numeric explanatory variables tested.

\begin{tabular}{lcr} 
& Mean \pm SD & Range \\
\hline Altitude $(\mathrm{m})$ & $212.10 \pm 67.30$ & $102.00-330.00$ \\
Inclination $\left({ }^{\circ}\right)$ & $3.77 \pm 4.52$ & $0.00-20.00$ \\
$\mathrm{Mg}(\mathrm{mg} / 100$ g soil) & $13.69 \pm 8.17$ & $4.00-40.00$ \\
$\mathrm{~K}(\mathrm{mg} / 100$ g soil) & $11.37 \pm 11.84$ & $2.00-77.00$ \\
$\mathrm{~N}(\mathrm{~kg} \mathrm{~N}$ ha-1 yr-1) & $149.51 \pm 140.92$ & $7.71-1221.95$ \\
$\mathrm{P}(\mathrm{mg} / 100$ g soil) & $8.43 \pm 5.69$ & $1.00-31.00$ \\
$\mathrm{pH}$ & $5.43 \pm 0.93$ & $4.00-7.30$ \\
No. of plant species & $16.55 \pm 6.48$ & $5.00-45.00$
\end{tabular}

measured a mean infection rate of $13 \%$ for Lower Saxony $(15-28 \%$ for other German regions) ranging from $0 \%$ to $50 \%$. Similar results were reported from Denmark (Jensen and Roulund, 2004) with an average infestation of $18.5 \pm 19 \%$ and Ireland (do Valle Ribeiro et al., 1996) where only 18 of 58 ecotypes were infected with the fungus with a maximum infection frequency of $27 \%$. In contrast, Zabalgogeazcoa et al. (2003) found a high incidence $(47 \%)$ of $\mathrm{N}$. lolii in Iberian permanent grasslands. Accordingly, Lewis et al. (1997) detected infections of Lolium spec. with N. lolii in 15 of 20 European countries. He discovered a significant correlation between the level of endophytic infection and summer drought in different regions of France. He found higher levels of infection in warmer regions of France such as the Mediterranean regions, including Corsica in comparison to the northern regions. Especially the parameters water supply deficit explained $43 \%$ and the evapotranspiration explained $47 \%$ of the measured variability.

Applied to the district of Northeim, it is typically not affected by summer drought. Water supply is at a sub-oceanic climate with an annual precipitation between 600 and $1050 \mathrm{~mm}$ per year. This might explain the low frequency of infection with N. lolii in this study in line with other studies mentioned above from northern and central Europe (see also Malinowski and Belesky, 2006). However, a local summer drought is possible at calcareous rocks due to its low water holding capacity. This characteristic probably plays a certain role for the correlation between limestone and N. lolii infection (see Section 4.3).

4.2. Land use intensity and type of grassland

In contrast to our hypothesis, neither the different levels of land use intensity (extensive, intermediate, intensive) nor the type of land use (meadows, mown pastures, pastures) had any significant impact on the abundance of $\mathrm{N}$. lolii. We hypothesized that in intensively managed grasslands the higher grazing pressure should result in higher levels of endophytic infection compared to the extensively managed ones, due to the selective feeding behavior of the grazing animals. Increases in the infection rate of Neotyphodium in grasses due to grazing pressure have been previously reported in several studies (Bazely et al., 1997; Jensen and Roulund, 2004; but see Saari et al. (2010)). Also Gwinn et al. (1998) observed a significant increase in the infection rate of $\mathrm{F}$. arundinacea with $\mathrm{N}$. coenophialum due to the grazing intensity of cattle at intermediate to high, but not at low levels of initial endophytic infection. In their study in Yukon Territory, Canada, Koh and Hik (2007) found a higher abundance of Neotyphodium spp. in Festuca altaica Trin. in grass patches intensively grazed by collared pikas (Ochotona collaris). In a choice test they found that pikas were able to discriminate between infected and non-infected grasses at high and intermediate, but not at low rates of infection. Those findings are in line with our results, which demonstrated a low level of fungal infection $(5.8 \pm 9.2 \%$ (mean \pm SD) $)$ and no significant differences between the three levels of grazing intensity. There is evidence that cattle as well are able to discriminate between infected and uninfected grasses (van Santen, 1992). However, the low infection levels at our sites may have prevented the discrimination ability of cattle in this study. In addition, the high number of other plant species $(17 \pm 7$ (mean \pm SD) ) within the plots investigated might have further reduced the incidence of taking up high levels of alkaloids produced by the fungus, thus also reducing the pressure on the cattle to discriminate between infected and non-infected grass tillers. Some studies also indicate that the effects of N. lolii in ryegrass are less pronounced in cool-moist environments (Eerens et al., 1998a) due to reduced alkaloid contents. Although we did not measure the level of lolitrem B and other fungal alkaloids, this effect might also play a role in our study. In summary, the low levels of infestation and the lack of selective pressure on the non-infected grasses could have resulted in a lack of significant differences between the three levels of grazing. 
In this study the level of land use intensity had no influence on the infection rate of grazed plots and the same was true for mown plots. Also Shelby and Dalrymple (1993) did not find any significant differences in the infection rate of tall fescue between mown and unmown plots in a four-year field study. The only exceptions were unmown, uninfected plots where the infection rate increased due to contamination (seed blowing) from adjacent unmown, infected plots. In addition, in field experiments with clipped meadow fescue Saari et al. (2010) showed negative effects of endophytes on regrowth in a one-year-old field and short-term greenhouse experiments but no detectable effects in older fields. This corresponds to our results as we always used fields older than one year in our study area. In contrast, Spyreas et al. (2001) found a higher infection rate of $\mathrm{N}$. coenophialum in mown rather than in unmown plots. They explained this with reduced soil moisture in mown plots and the enhanced competitive abilities of endophyte-infected grasses under drought stress. As drought stress was not a prevailing factor in our study area this might explain why the intensity of land use had no influence on the infection rate of mown plots. As discussed above, the grazing intensity as well had no influence on the abundance of the endophytic fungus, which might be the reason for the lack of difference between the three types of grassland.

\subsection{Geology}

In the process of model selection, geology remained the only factor that significantly influenced the abundance of N. lolii; ryegrass tillers collected from fields growing on limestone substrates had significantly higher infection rates than tillers from fields with other bedrock. This finding might be associated with the different field capacity (water holding capacity) of the soils. Limestone has a poor field capacity due to the thin organic layer and a high skeletal fraction of the soil. Accordingly, water drains away more quickly from calcareous soils than from other soil types. Hence, plants growing on carbonate soils are more likely to suffer from summer drought stress. In contrast, loess generally has a deep soil layer and a high field capacity. The field capacity of sandstone, fluvial soil and solifluction soil is intermediate (Scheffer et al., 2010). As mentioned above, summer drought is typically not a problem in the rural district of Northeim. However, some exceptionally dry summers are possible (e.g. in 2008), so that local and temporal water stress can occur at those sites on limestone soils. As mentioned in Section 2, the year 2008 was warmer and dryer than the mean reference values of the last 30 years in the study area, whereas the values for 2009 were within the average. Hence, the summer drought in 2008 could have triggered the higher abundance of endophyteinfected grasses in this and in the following year on limestone soils in comparison to the other soils.

There are several studies showing the enhanced performance of endophyte-infected grasses under drought stress (Arachevaleta et al., 1989; Malinowski et al., 1997). Different mechanisms can be involved with regard to these findings: drought avoidance of endophyte-infected grasses through increased root hair lengths and a decreased root diameter, drought tolerance through better osmotic adjustment, and increased water use efficiency, respectively (reviewed in Malinowski and Belesky, 2000).

Also Hesse (2002) found higher abundances of infected L. perenne genotypes on dry sites compared to wet sites in Germany. In additional greenhouse experiments she observed that infected genotypes collected at dry and periodically flooded/dry sites performed better under waterlimited conditions. On the other hand, infected ryegrass genotypes collected at wet sites were more sensitive to drought stress (Hesse et al., 2003). They concluded that the plant-endophyte associations are adapted to their native habitats via natural selection.
In addition, Eerens et al. (1998b) observed in greenhouse experiments with L. perenne that infected plants were less wilted under high temperature and water stress. Surprisingly, they also found that endophyte-free plants experienced higher weight and higher water use efficiencies. In contrast, Barker et al. (1997) did not find any effects of endophytic infection in L. perenne under drought stress and even detrimental effects (Cheplick et al., 2000) were reported.

At sites with limestone bedrock we did not only find higher incidences of $\mathrm{N}$. lolii but also higher $\mathrm{pH}$-values and the highest amount of potassium $(\mathrm{K})$, as compared to soil solution of sandstone bedrock and the other soil types. The amount of exchangeable potassium is positively correlated with the pH-value of the soil.

Sandstone contains a lower amount of potassium due to leaching, whereas the exchangeable potassium in loess, fluvial soil, and solifluction soil is less available for plants due to adsorption (Scheffer et al., 2010).

There is some evidence that endophytes can influence the potassium uptake of grasses. Khayamim et al. (2010) observed that endophytic infection of F. arundinacea significantly increased the potassium uptake and the weathering rate of the K-bearing mineral phlogopite under K-free solution. They suggested the release of organic acids as a possible mechanism for this finding as they additionally noticed a decreased $\mathrm{pH}$ value in the rhizosphere of infected plants.

Especially in grassland, potassium is an important nutrient (Kayser and Isselstein, 2005), able to enhance the drought stress tolerance of grasses as suggested by Bayat et al. (2009). They found higher contents of potassium in the shoots of infected F. arundinacea under drought stress and a significantly higher survival of infected plants after stress removal. They concluded that potassium might be of great importance for osmotic adjustment and stomatal conductance of drought-stressed plants. Sabzalian and Mirlohi (2010) also found higher $\mathrm{K}^{+}$concentrations in the shoots of endophyte-infected tall and meadow fescue and an enhanced survival under salinity stress.

According to our study correlations between rate of infection, soil type, potassium content and $\mathrm{pH}$-value are in line with related studies and can probably be explained by soil conditions and "ecophysiological" reactions. Not only the drought stress but also the availability of $\mathrm{K}$ at calcareous soils and the increased K-uptake of infected grasses could have contributed to the propagation of infected $L$. perenne.

We have observed that geology can significantly influence the abundance of the endophytic fungus N. lolii in L. perenne. Grasses on soils with low field capacity, like limestone, are more likely to suffer from summer drought resulting in higher incidences of $\mathrm{N}$. lolii. Under climate change conditions summer drought could become more common. The increased incidence of endophytic fungi could cause livestock toxicosis especially on grasslands with low field capacity and high grazing pressure. Therefore, geology of the sites should be considered when considering grassland management strategies.

\section{Acknowledgements}

We thank Christoph Scherber for his support with the statistical analysis and the local farmers in the rural district of Northeim for their cooperation. We also thank Mike Dobrindt for reviews and suggestions. This study was funded by the Ministry of Science and Culture of Lower Saxony and the "Niedersächisches Vorab". 


\section{References}

Ahlholm, J.U., Helander, M., Lehtimäki, S., Wäli, P., Saikkonen, K., 2002. Vertically transmitted fungal endophytes: different responses of host-parasite systems to environmental conditions. Oikos 99, 173-183.

Arachevaleta, M., Bacon, C.W., Hoveland, C.S., Radcliffe, D.E., 1989. Effect of the Tall Fescue Endophyte on Plant Response to Environmental Stress. Agronomy journal 81, 83-90.

Bacon, C.W., Porter, J.K., Robbins, J.D., Luttrell, E.S., 1977. Epichloe-Typhina from Toxic Tall Fescue Grasses. Applied and Environmental Microbiology 34, 576-581.

Barker, D.J., Hume, D.E., Quigley, P.E., 1997. Negligible physiological responses to water deficit in endophyte-infected and uninfected perennial ryegrass. In: Eds Bacon CW, H.N. (Ed.), Neotyphodium/Grass Interactions. Plenum Press, pp. 137-139.

Bayat, F., Mirlohi, A., Khodambashi, M., 2009. Effects of endophytic fungi on some drought tolerance mechanisms of tall fescue in a hydroponics culture. Russian Journal of Plant Physiology 56, 510-516.

Bazely, D.R., Vicari, M., Emmerich, S., Filip, L., Lin, D.,Inman, A., 1997. Interactions between Herbivores and Endophyte-Infected Festuca rubra from the Scottish Islands of St. Kilda, Benbecula and Rum. Journal of applied ecology 34, 847-860.

Bockholdt, R., Fuhrmann, U., Briemle,G. 1996: Anleitung zur korrekten Einschätzung von Intensitätsstufen der Grünlandnutzung. Natur \& Landschaft 71/6: 249-251.

Breen, J.P., 1994. Acremonium endophyte interactions with enhanced plant resistance to insects. Annual Review of Entomology 39, 401.

Bush, L.P., Wilkinson, H.H., Schardl, C.L., 1997. Bioprotective alkaloids of grass-fungal endophyte symbioses. Plant physiology $114,1$.

Cheplick, G.P., Perera, A., Koulouris, K., 2000. Effect of drought on the growth of Lolium perenne genotypes with and without fungal endophytes. Functional Ecology 14, 657-667.

Clay, K., 1988. Fungal Endophytes of Grasses: A Defensive Mutualism between Plants and Fungi. Ecology 69, 10-16.

Dierschke, H., Briemle, G., 2002. Kulturgrasland. Ökosysteme Mitteleuropas aus geobotanischer Sicht.

do Valle Ribeiro, M.A.M., K.A., G., Bush, L.P., 1996. Endophyte Acremonium lolii in Ecotypes of Perennial Ryegrass (Lolium perenne L.) Collected in Old Irish Pastures. Irish journal of agricultural and food research 35, 151-157.

Eerens, J.P.J., Lucas, R.J., Easton, H.S., White, J.G.H., 1998 a. Influence of the ryegrass endophyte (Neotyphodium lolii) in a cool moist environment. I. Pasture production. New Zealand Journal of Agricultural Research 41, 39-48.

Eerens, J.P.J., Lucas, R.J., Easton, S., White, J.G.H., 1998 b. Influence of the endophyte (Neotyphodium lolii) on morphology, physiology, and alkaloid synthesis of perennial ryegrass during high temperature and water stress. New Zealand Journal of Agricultural Research 41, 219-226.

Faeth, S.H., Fagan, W.F., 2002. Fungal endophytes: Common host plant symbionts but uncommon mutualists. Integrative and Comparative Biology 42, 360-368.

Fletcher, L.R., Harvey, I.C., 1981. An association of a Lolium endophyte with ryegrass staggers. New Zealand veterinary journal 29, 185186.

Gwinn, K.D., Fribourg, H.A., Waller, J.C., Saxton, A.M., Smith, M.C., 1998. Changes in Neotyphodium coenophialum infestation levels in tall fescue pastures due to different grazing pressures. Crop Science 38, 201-204.

Hesse, U., 2002. Untersuchungen zur Endophytbesiedelung vonGräserökotypen und zu Symbioseeffekten durch Neotyphodium lolii in Lolium perenne-Genotypen hinsichtlich Stresstoleranz und Ertragsmerkmale. [Studies on endophyte presence in grass ecotypes and on symbiotic effects by Neotyphodium lolii on Lolium perenne genotypes in relations to their stress tolerance and yield] Martin-Luther-Universität Halle-Wittenberg.

Hesse, U., Schöberlein, W., Wittenmayer, L., Förster, K., Warnstorff, K., Diepenbrock, W., Merbach, W., 2003. Effects of Neotyphodium endophytes on growth, reproduction and drought-stress tolerance of three Lolium perenne L. genotypes. Grass and Forage Science 58, 407-415.

Hesse, U., Hahn, H., Andreeva, K., Forster, K., Warnstorff, K., Schoberlein, W., Diepenbrock, W., 2004. Investigations on the influence of Neotyphodium endophytes on plant growth and seed yield of Lolium perenne genotypes. Crop Science 44, 1689-1695.

Jensen, A.M.D., Roulund, N., 2004. Occurrence of Neotyphodium endophytes in permanent grassland with perennial ryegrass (Lolium perenne) in Denmark. Agriculture, Ecosystems \& Environment 104, 419-427.

Kayser, M., Isselstein, J., 2005. Potassium cycling and losses in grassland systems: a review. Grass and Forage Science 60, $213-224$. 
Khayamim, F., Khademi, H., Sabzalian, M., 2010. Effect of Neotyphodium endophyte-tall fescue symbiosison mineralogical changes in clay-sized phlogopite and muscovite. Plant and Soil 341, 473-484.

Klimek, S., Richter, G., Kemmermann, A., Hofman, M., Isselstein, J., 2007. Plant species richness and composition in managed grasslands: The relative importance of field management and environmental factors. Biological Conservation 134, 559-570.

Koh, S., Vicari, M., Ball, J.P., Rakocevic, T., Zaheer, S., Hik, D.S., Bazely, D.R., 2006. Rapid detection of fungal endophytes in grasses for large-scale studies. Functional Ecology 20, 736-742.

Koh, S., Hik, D.S., 2007. Herbivory Mediates Grass-Endophyte Relationships. Ecology 88, 2752-2757.

Leuchtmann, A., 1993. Systematics, distribution, and host specificity of grass endophytes. Natural Toxins 1, 150-162.

Lewis, G.C., Ravel, C., Naffaa, W., Astier, C., Charmet, G., 1997. Occurrence of Acremonium endophytes in wild populations of Lolium spp. in European countries and a relationship between level of infection and climate in France. Annals of Applied Biology 130, 227-238.

Malinowski, D., Leuchtmann, A., Schmidt, D., Nosberger, J., 1997. Symbiosis with Neotyphodium uncinatum endophyte may increase the competitive ability of meadow fescue. Agronomy Journal 89, 833-839.

Malinowski, D.P., Belesky, D.P., 2000. Adaptations of endophyte-infected cool-season grasses to environmental stresses: Mechanisms of drought and mineral stress tolerance. Crop Science 40, 923-940.

Malinowski, D.P., Belesky, D.P., 2006. Ecological importance of Neotyphodium spp. grass endophytes in agroecosystems. Grassland science $52,1$.

Oldenburg, E., 1997. Endophytic fungi and alkaloid production in perennial ryegrass in Germany. Grass and Forage Science 52, 425-431.

Saari, S., Helander, M., Lehtonen, P., Wallius, E., Saikkonen, K., 2010. Fungal endophytes reduce regrowth and affect competitiveness of meadow fescue in early succession of pastures. Grass and Forage Science 65, 287-295.

Sabzalian, M., Mirlohi, A., 2010. Neotyphodium endophytes trigger salt resistance in tall and meadow fescues. Journal of plant nutrition and soil science 173, 952-957.

Saikkonen, K., Faeth, S.H., Helander, M., Sullivan, T.J., 1998. Fungal Endophytes: A Continuum of Interactions with Host Plants. Annual Review of Ecology and Systematics 29, 319-343.

Saikkonen, K., Ahlholm, J., Helander, M., Lehtimäki, S., Niemeläinen, O., 2000. Endophytic fungi in wild and cultivated grasses in Finland. Ecography 23, 360-366.

Saikkonen, K., Lehtonen, P., Helander, M., Koricheva, J., Faeth, S.H., 2006. Model systems in ecology: dissecting the endophyte-grass literature. Trends in Plant Science 11, 428-433.

Saikkonen, K., Saari, S., Helander, M., 2010. Defensive mutualism between plants and endophytic fungi? Fungal Diversity 41, 101-113.

Scheffer, F., Schachtschabel, P. , Blume, H. P. (Ed), 2010. Lehrbuch der Bodenkunde. Spektrum, Akad.-Verl., 2010.

Shelby, R.A., Dalrymple, L.W., 1993. Long-term changes of endophyte infection in tall fescue stands. Grass and Forage Science 48, 356361.

Spyreas, G., Gibson, D.J., Middleton, B.A., 2001. Effects of endophyte infection in tall fescue (Festuca arundinacea : Poaceae) on community diversity. International journal of plant sciences 162, 1237-1245.

Stroh, H.G., Klimek, S., Isselstein, J., 2009. Farm structure and grassland phytodiversity - a comparison of beef and dairy cattle farms. Grassland Science in Europe 14, 46-49.

van Santen, E., 1992. Animal preference of tall fescue during reproductive growth in the spring. Agronomy journal 84, 979.

Venables, W.N., Ripley, B.D., 2002. Modern Applied Statistics with S.

Wilson, D., 1995. Endophyte - the Evolution of a Term, and Clarification of Its Use and Definition. Oikos 73, 274-276.

Weibull, A.-C., Östman, Ö., Granqvist, A., 2003. Species richness in agroecosystems: the effect of landscape, habitat and farm management. Biodiversity and Conservation 12, 1335-1355.

Zabalgogeazcoa, I., De Aldana, B.R.V., Ciudad, A.G., Criado, B.G., 2003. Fungal endophytes in grasses from semi-arid permanent grasslands of western Spain. Grass and Forage Science 58, 94-97.

Zabalgogeazcoa, I., Bony, S., 2008. Neotyphodium Research and Application in Europe. Neotyphodium in Cool-Season Grasses. Blackwell Publishing Ltd, pp. 23-33. 


\section{Chapter 2: Influence of grassland management on the abundance of the endophytic fungus Neotyphodium in a permanent grassland}

\section{Lana Dobrindt ${ }^{1}$ and Stefan Vidal ${ }^{1}$}

${ }^{1}$ Georg-August-University Göttingen, Department of Crop Science, Agricultural Entomology, Grisebachstrasse 6, 37077 Göttingen, Germany, phone: ++49(0)55139 3733, Email: Idobrin@gwdg.de

Corresponding author: S. Vidal, address as above, phone: $+49(0) 551-399744$, fax: +49(0)551 -39 12105, Email: svidal@gwdg.de

\section{ABSTRACT}

The endophytic fungus Neotyphodium spec. is common in many temperate grass species and is known to enhance the plant's growth and stress tolerance. Although the endophyte-host association is usually considered as mutualistic this assumption could be biased, as many studies were conducted in nutrient-rich, intensively managed grasslands. The objective of this study was to investigate how grassland management regimes influence the abundance of Neotyphodium in a nutrient-poor, semi-natural permanent grassland. The study was carried out in the Solling Uplands, central Germany, over a period of three years. We examined the impact of mowing frequency, fertilizer and herbicide application on the infection rate of four grass species. The overall infection rate in the four grass species tested was low $(2.6 \%)$. The cutting frequency and the herbicide application did not influence the abundance of Neotyphodium. In contrast, fertilized plots had significantly higher levels of infection than unfertilized plots. We conclude that fertilization reduced the competition of the host-endophyte association for nutrients and shifted the symbiosis from antagonistic to mutualistic. Therefore, the nutrient status of the soil is an important factor for the outcome of the endophyte-grass interaction.

Keywords: endophytic fungus, grasses, grassland management, nutrients, mutualism, antagonism 


\section{INTRODUCTION}

Endophytic fungi have been found in all plant species examined to date (Arnold et al., 2000). Wilson (1995) defined endophytes as microorganisms living within the plant's tissue without causing any visible symptoms of disease. The unspecialized endophytes of woody plants form local infections and are transmitted horizontally via spores (Faeth, 2002). In contrast, the specialized endophytic fungi of coolseason grasses colonize the aboveground parts of their host systemically and are exclusively transmitted via their host's seeds (Clay, 1990). Vertically transmitted endophytic fungi of the genus Neotyphodium Glenn, Hanlin and Bacon are widespread in many temperate grass species (Leuchtmann, 1993; Leyronas and Raynal, 2001; Novas et al., 2007). The symbiosis between the fungus and the host is commonly viewed as mutualistic (Clay, 1988; Breen, 1994). The endophyte produces various alkaloids such as ergovaline, lolitrem B, loline alkaloids and peramine which enhance the host plant's resistance to herbivores (Bush et al., 1997). While peramine is a feeding deterrent to herbivorous insects (Latch, 1993), Iolitrem $B$ and ergovaline are toxic to livestock and can cause a nervous disorders called "ryegrass staggers" and the fescue toxicosis (Bacon et al., 1977; Fletcher and Harvey, 1981). Moreover, Neotyphodium endophytes are able to increase their host's resistance to abiotic stresses such as drought and salinity stress and to enhance the uptake of water and nutrients (Malinowski and Belesky, 2000; Sabzalian and Mirlohi, 2010). Grasses infected with Neotyphodium are also known to have an enhanced growth and to produce more tillers than uninfected plants (Latch et al., 1985). In return, the host grass supplies the endophyte with water and nutrients, provides shelter and ensures its dissemination (Clay, 1988; Breen, 1994).

However, the grass-endophyte association can range from mutualistic to antagonistic as a result of host-genotype interactions, environmental conditions and nutrient availability (Saikkonen et al., 1998; Wäli et al., 2008; Saona et al., 2010). Hesse et al. (2003) demonstrated in a greenhouse experiment that Lolium perenne L. genotypes collected at wet sites in Germany were more sensitive to drought stress than uninfected plants. In addition, L. perenne genotypes collected at dry sites performed better under water-limited conditions than uninfected plants. 
Similarly, Cheplick et al. (1989) reported that endophyte-infected tall fescue (Festuca arundinacea Schreb.) produced more biomass under high nutrient levels compared to uninfected plants. Nevertheless, the biomass of infected plants was decreased in comparison to uninfected plants under nutrient-limited conditions. Hence, the beneficial effects of endophytes might be promoted by fertilization and other management regimes in agriculturally used grasslands. The outcome of the endophyte-host association could be more variable in natural environments (Saikkonen et al., 2006; Saikkonen et al., 2010). However, many studies dealing with endophytic fungi were carried out in either sown, experimental fields or were surveys of naturally occurring grasslands (Leyronas and Raynal, 2001; Faeth 2002).

The present study was conducted within the framework of the interdisciplinary Grassland Management Experiment (GrassMan) investigating the influence of management regimes on grassland productivity and ecosystems functions. The approach of this study was to investigate the impact of different treatments (mowing, fertilizer and herbicide application) on the abundance of Neotyphodium spec. in an old, semi-natural grassland. The abundance of the endophytic fungus in a grass population is considered as a good measure for the fitness of a grassendophyte association (Saona et al., 2010). In a mutualistic association the level of infection is likely to increase over time as shown in several studies (Gwinn et al., 1998; Spyreas et al., 2001), whereas it should decrease if the association is antagonistic (Saari et al., 2010).

We hypothesize that:

1) Fertilization increases the level of endophytic infection in the grassland due to the reduced competition for nutrients between the host and the endophyte Cheplick et al. (1989).

2) Frequent mowing might be stressful to grasses and simulate herbivory, which is known to increase the level of endophytic infection (Koh and Hik, 2007). Therefore, the abundance of Neotyphodium should increase in the more frequently mown plots.

3) Endophyte-infected grasses were shown to decrease the plant species' diversity of the sward (especially that of the forbs) in comparison to 
uninfected grasses (Clay and Holah, 1999). The removal of forbs in response to herbicide application in the dicotyle - reduced plots (Dic-) should reduce the competition for resources of the remaining plants and enable uninfected grasses to propagate as well. Therefore, we expect the level of endophytic infection to decrease in the Dic- plots in comparison to the control plots.

\section{MATERIALS AND METHODS}

\section{Study area and experimental design}

This study was conducted as a part of the interdisciplinary "GrassMan"-project at the University of Göttingen. This project aims to investigate the impact of grassland management on plant diversity, productivity and ecosystems functions. The study area, a semi-natural, old permanent grassland was located in the Solling Uplands, Lower Saxony, central Germany (514ㄴ'53" N, 9³2'43" E, 490 m a. s. I.). Its usage as an extensive pasture and meadow is documented since the end of the $19^{\text {th }}$ century (Petersen et al., in press). The mean annual temperature is $6.9^{\circ} \mathrm{C}$ with an annual precipitation of $1030 \mathrm{~mm}$ (Deutscher Wetterdienst 1960 1990). The vegetation is characterized as nutrient-poor, mesic-moist LolioCynosuretum, the soil type is haplic Cambisol on middle Bunter sandstone. The soil is shallow with a maximum depth of $60 \mathrm{~cm}$ and the $\mathrm{pH}(\mathrm{KCL})$ varies between 5.2 - 5.6 (Hoeft and Keuter, unpublished). Prior to the beginning of the treatments in 2008 soil samples were taken from all over the grassland and analyzed for nutrient contents and other parameters (for further details see Petersen et al., in press). This was done in order to detect potential gradients in nutrients or soil depth and to be able to take them into account. In addition, the whole study was fenced to exclude large mammalian herbivores such as deer and wild boars.

The full-factorial design included the three factors sward, nutrients and utilization with three factor levels for sward and two factor levels for nutrients and utilization, respectively (Tab. 1). Each treatment was replicated six times on $15 \times 15$ m plots, 
which resulted in 72 plots in total. The plots were arranged in a Latin Square design with six rows and 6 blocks (one block consisting of two columns) in order to account for possible gradients in nutrients or slopes in the grassland. The Monocot reduced (Mon-) plots were obtained by application of Clethodim $\left(0.5 \mathrm{l} \mathrm{ha}{ }^{-1}\right)$ and the dicot reduced (Dic-) plots by application of Fluoroxypyr + Triclopyr and Mecoprop-P (3l ha-1 ${ }^{-1}$ respectively). Both herbicides were applied in the initial year of the experiment after the first mowing. At the fertilized plots (NPK), N-fertilizer was applied as calcium ammonium nitrate N27, whereas PK was supplied as Thomaskali® (8\% P2O5, 15\% K2O, 20\% CaO).

Tab. 1: Treatments and their levels used in the "GrassMan" -Experiment

\begin{tabular}{|c|c|c|}
\hline Treatment & Level & Specifications \\
\hline Sward & 1.1 Control (Co) & \\
\hline Sward & 1.2 Dicot reduced (Dic-) & $\begin{array}{l}\text { Herbicide application / end of July } \\
2008\end{array}$ \\
\hline Sward & 1.3 Monocot reduced (Mon-) & $\begin{array}{l}\text { Herbicide application / end of July } \\
2008\end{array}$ \\
\hline Utilization & 2.1 One cut/ year & July (cutting height $7 \mathrm{~cm}$ ) \\
\hline Utilization & 2.2 Three cuts/ year & $\begin{array}{l}\text { May, July, September (cutting } \\
\text { height } 7 \mathrm{~cm} \text { ) }\end{array}$ \\
\hline Nutrients & 3.1 No fertilization & \\
\hline Nutrients & 3.2 Fertilization (NPK) & $\begin{array}{l}180 / 30 / 100 \mathrm{~kg} \mathrm{ha}^{-1} \mathrm{yr}^{-1} \text {, in } 2008 \\
\text { only } 50 \mathrm{~kg} \mathrm{~N} \mathrm{ha}^{-1}\end{array}$ \\
\hline
\end{tabular}

\section{Sampling}

The first sampling was carried out in the middle of June 2008 before the beginning of mowing, fertilizer and herbicide application. The purpose was to determine the baseline-abundance of Neotyphodium spec. in the grasses before the beginning of the treatments. For this investigation, the most abundant grass species in the study area were chosen: Festuca rubra L. (two samples/plot), Poa trivialis L. (two samples/plot), L. perenne (one sample/plot) and Dactylis glomerata L. (one sample/plot). Only the Dic- and the Control plots were sampled. The Mon- plots 
were left out because of the presumably low abundance of grasses in the subsequent years. The sampling was repeated in July 2009, one year after the beginning of the treatments and before the mowing of all plots. In 2010 we decided to increase the sample size to 18 plants per plot in order to reduce the variability in the infection rate of the grasses and to improve the statistical analysis. In July 2010 we collected two samples of $F$. rubra, ten samples of $P$. trivialis, five samples of $L$. perenne and one sample of $D$. glomerata per plot.

In all years, the collected plants were labeled and transported to the laboratory in a cool box immediately after sampling. Until further investigation they were frozen in nylon bags at $-20{ }^{\circ} \mathrm{C}$.

\section{Detection of Neotyphodium}

The collected plants were tested for the infection rate of Neotyphodium spec. with the ELISA-based Phytoscreen field tiller kits acquired from the company Agrinostics, Watkinsville, GA, USA. The kits were developed for the detection of Neotyphodium spec. in the common pasture and turf grasses Festuca arundinacea Schreb. and L. perenne. Koh et al. (2006) showed in their study that these kits are applicable for the detection of Neotyphodium spec. in many other grass species at a large scale. The sampled grass tillers were cut into crosssections and placed on an immunoblot membrane. The membrane was incubated over night in a refrigerator at $4\left({ }^{\circ} \mathrm{C}\right)$, which enabled the fungal proteins to bind on its surface. On the next day, antibodies specific to Neotyphodium spec., an enzyme and a chromogen solution were consecutively added to the membrane. Tillers infected with the fungus developed a pink imprint. In contrast, the imprint of uninfected tillers remained uncolored.

\section{Statistical analysis}

The data was analyzed using R 2.9.2 (R Development Core Team, 2009) with a generalized linear mixed model (GLMM), (Ime4 package, (Bates and Maechler, 
2009)) with binomial distribution and logit link function. As the individual infection rate of some grass species was very low, endophytic infection of all grass species together was taken as the dependent variable and year, sward, nutrients, utilization as explanatory variables. Also, the two way and three way interactions of sward, nutrients and utilization were analyzed. In addition, row and block of the Latin Square were included as fixed effects to incorporate the spatial heterogeneity of the study site. The year and plot ID were taken as random effects to account for temporal and spatial dependence of the sampled plots. Also, the grass species were taken as a random effect to account for the potentially different response of the grass species to the treatments. The Akaike information criterion (AIC) was used to obtain the minimal adequate model in which only the significant terms were incorporated. Linear contrasts from the R-package MASS (Venables and Ripley, 2002) were used to test for difference between treatments and factor levels.

\section{RESULTS}

The overall incidence of Neotyphodium spec. in the four sampled grass species before the beginning of the treatments (baseline) in 2008 was $15 \pm 3 \%$ (Fig.1). $P$. trivialis and $L$. perenne had the highest infection rates followed by $D$. glomerata and $F$. rubra. In 2009, one year after the beginning of the treatments, the overall infection level of all sampled grass species increased to $17.8 \%$ (Fig.2). Also in 2009, Neotyphodium spec. was most abundant in P. trivialis and L. perenne with a lower level of infection in D. glomerata. As in 2008, F. rubra was the grass species with the lowest level of infection. In 2010, the overall rate of infection decreased to $2.6 \%$ with $D$. glomerata being the grass species with the highest rate of infection, followed by $L$. perenne and $P$. trivialis. $F$. rubra had the lowest incidence of the endophytic fungus. 


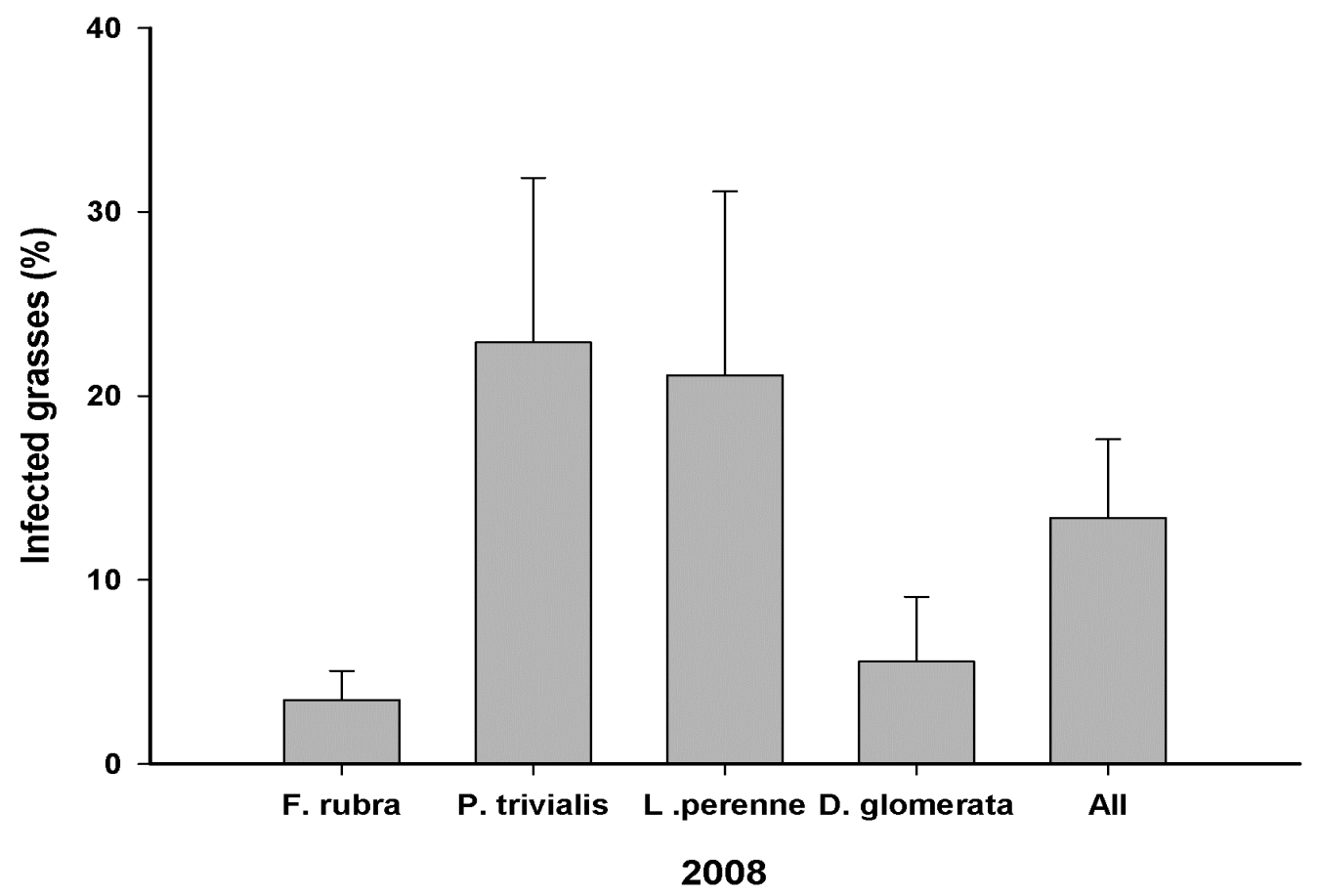

Fig. 1: Percentage of grass tillers from different grass species (mean $+S E$ ) infected with Neotyphodium spec. in the year 2008.

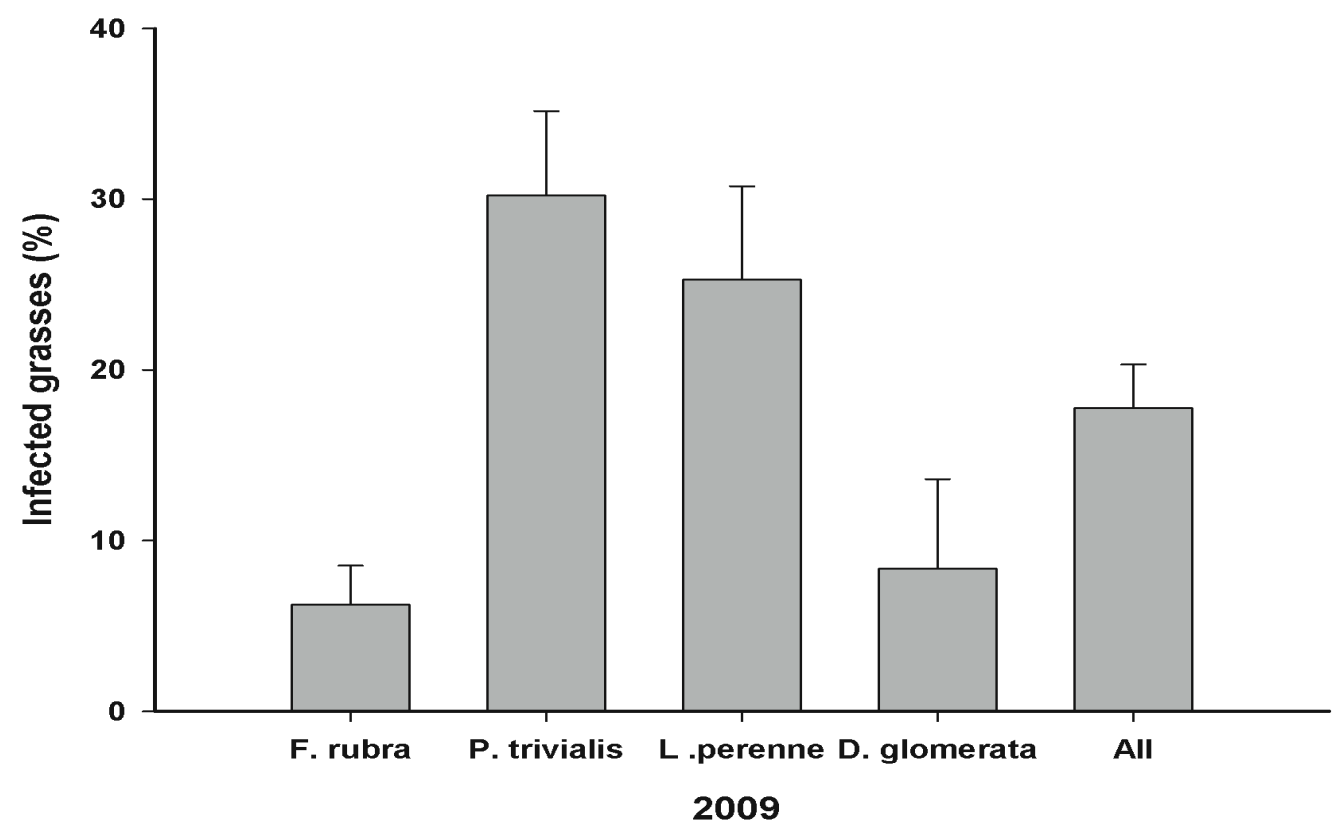

Fig. 2: Percentage of grass tillers from different grass species (mean $+S E$ ) infected with Neotyphodium spec. in the year 2009. 
The herbicide application in the Dic- treatment almost entirely removed the legumes whereas only around $8 \%$ of the forbs were left (Petersen et al., in press). The composition of the sward and the cutting frequency did not significantly influence the abundance of Neotyphodium spec. in the four investigated grass species (Tab. 2). Also the interaction of sward and utilization with each other and their two-way interactions with nutrients were not significant. The three-way interaction of the factors sward, nutrients and utilization was not significant as well. In contrast, the year of sampling had an effect on the incidence of the endophytic fungus, as fertilization significantly influenced the abundance of Neotyphodium spec. in the investigated grass species in 2009 and 2010 (Fig. 3, Fig. 4). Plots treated with nutrients (NPK) had higher rates of infection than untreated plots. In 2008 , before the beginning of the treatments this difference was not significant $(P$ $=0.164)$. The row and block that were taken as fixed effects to account for potential inhomogeneity of the study site had no significant influence on the abundance of Neotyphodium spec. in the four grass species tested.

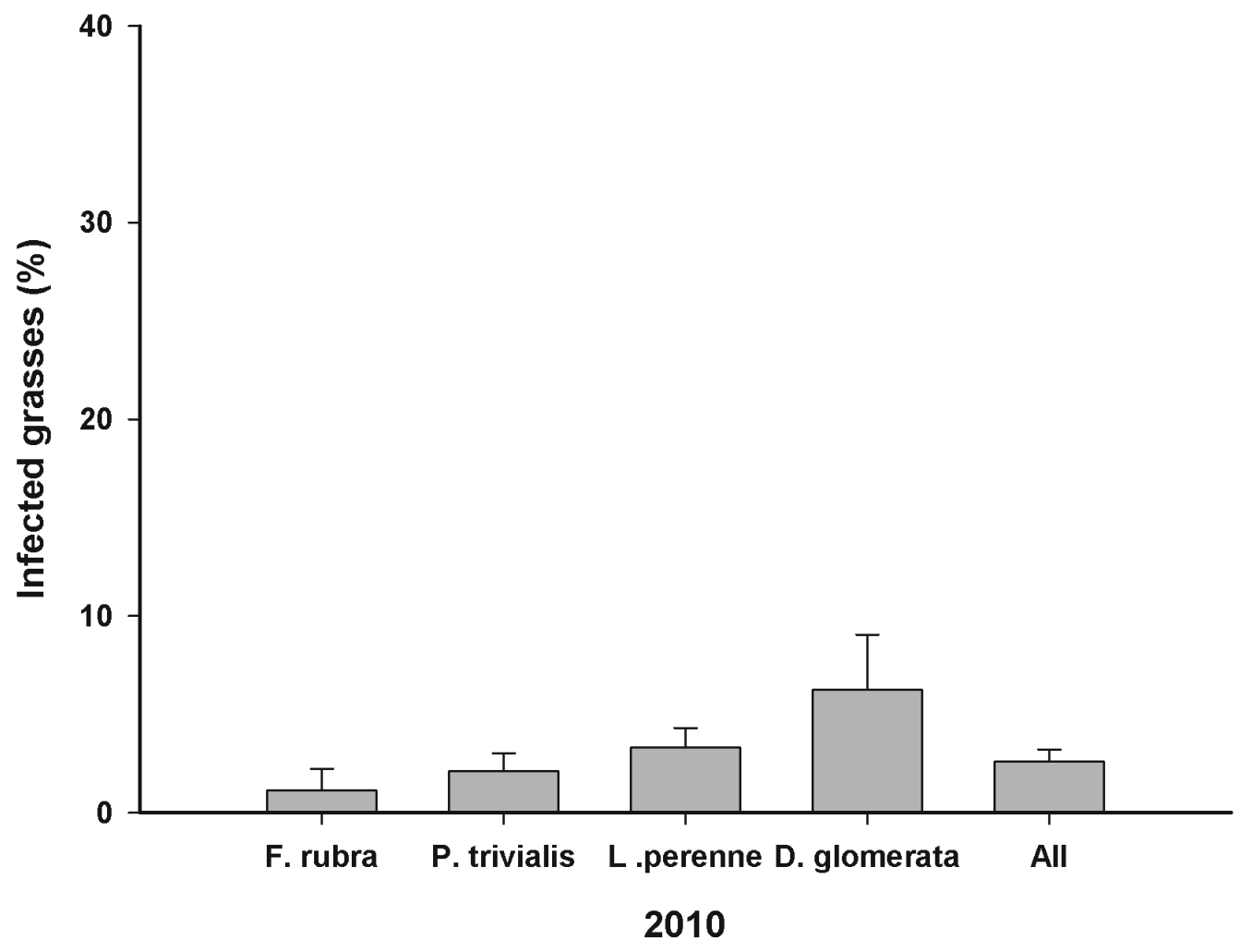

Fig. 3: Percentage of grass tillers from different grass species (mean $+\mathrm{SE}$ ) infected with Neotyphodium spec. in the year 2010. 


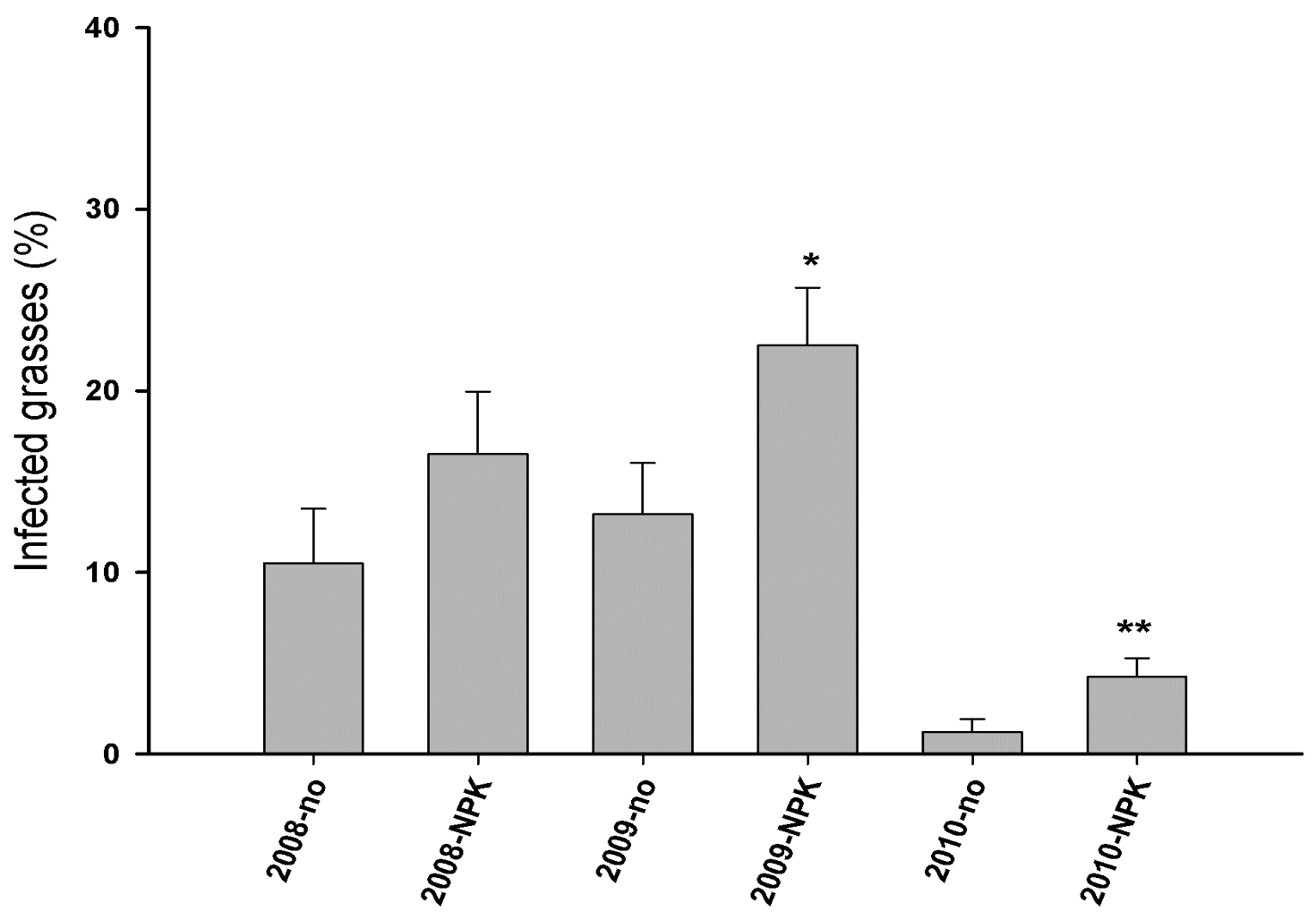

Fig. 4: Percentage of grass tillers of all sampled grass species (mean $+\mathrm{SE}$ ) infected with Neotyphodium spec. in the years 2008-2010. "NPK" refers to the fertilized nutrient treatment; "no" refers to the non-fertilized treatment. Asterisks above columns indicate significance of difference between treatments with a year

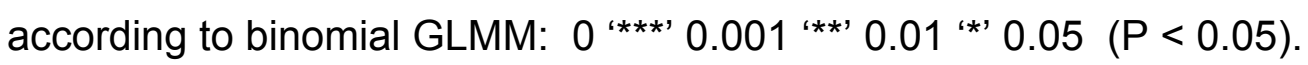


Tab. 2: Effects of treatments, their interactions and other fixed effects on the infection rate of Neotyphodium spec. in the four grass species tested

\begin{tabular}{llll}
\hline Factor & Std. Error & z -value & P-value \\
\hline Block & 0.0598 & 0.3990 & 0.6897 \\
Row & 0.0589 & -0.2900 & 0.7721 \\
Year & 0.1178 & -6.9880 & $2.78 \mathrm{e}-12^{* * *}$ \\
Nutrients & 0.2138 & 3.6180 & $0.0003^{* * *}$ \\
Sward & 0.2047 & -0.6750 & 0.4996 \\
Utilization & 0.2048 & 0.5960 & 0.5512 \\
Nutrients x Sward & 1.3706 & 0.8940 & 0.3710 \\
Nutrients x Utilization & 1.3332 & 1.1340 & 0.2570 \\
Sward x Utilization & 1.4814 & 0.6770 & 0.4980 \\
Nutrients x Sward x & 0.8645 & -0.7940 & 0.4270 \\
Utilization & & & \\
\hline
\end{tabular}

The data was analyzed with a generalized linear mixed model (GLMM) with binomial distribution and logit link function. Significance codes: 0 ‘*** 0.001 '**' $0.01^{\text {‘*’ } 0.05(P<0.05)}$

\section{DISCUSSION}

\section{Level of endophytic infection}

In the years 2008 (Fig. 1) and 2009 (Fig. 2) the level of endophytic infection showed much variation between and within the four grass species. In 2008, Neotyphodium spec. was most abundant in $P$. trivialis and $L$. perenne followed by D. glomerata and F. rubra. In 2009, the levels of fungal infection in the four grass species were similar to those in 2008 although the overall rate of infection and the level of infection of each grass species were slightly increased. The increase in the overall rate of infection in 2008 compared to 2009 can be explained by the supply of nutrients to the NPK-plots. This effect will be discussed below. In 2010 (Fig. 3), the overall rate of infection with Neotyphodium spec. was lower than in 2008 and 
2009, especially in $P$. trivialis and $L$. perenne. The reason for that could be that in 2010, we increased the sample size of those grass species in order to reduce the variance and to gain a more reliable data on the abundance of Neotyphodium spec. Therefore, as we think that this data is more accurate than that from previous years, we will use only this data for the discussion of the infection level of Neotyphodium spec.

In 2010, the overall infection of all grasses was low (2.6\%). Neotyphodium spec. was most abundant in D. glomerata $(6.3 \%)$ followed by L. perenne $(3.3 \%)$, $P$. trivialis $(2.1 \%)$ and $F$. rubra $(1.1 \%)$. The infection rate for $P$. trivialis is similar to those observed by Bazely et al. (2007) in their study on naturally occurring grass populations in Sweden. They detected infections in 11 of 54 populations of $P$. trivialis with an overall infection frequency of $4 \%$. In contrast to our results they measured a higher overall infection frequency in F. rubra (27\%) with 27 of 49 populations being infected. In addition, they observed a significant negative correlation between the infection frequency of $F$. rubra and the altitude of the sampled site. At the altitude of $500 \mathrm{~m}$ the level of infection was $<5 \%$, which corresponds with our results, as our study site was located $490 \mathrm{~m}$ a. s. I. They explained their observation with decreased water availability at lower altitudes that might favor infected plants. In Finland, (Saikkonen et al., 2000) found a mean infection rate of $32 \%$ for $F$. rubra in natural grasslands and a mean infection rate for $D$. glomerata of $17 \%$, whereas only one of 11 populations was infected with Neotyphodium spec. This is similar to our results, as $D$. glomerata was also not very abundant at our study site. Furthermore, the level of endophytic infection in $L$. perenne was also low. That is comparable to other studies from German grasslands (Oldenburg, 1997). For Lower Saxony, the federal state where our study site is located, she reported a mean infection frequency of $13 \%$ ranging from $0 \%$ to $50 \%$.

In contrast, a high incidence of Neotyphodium spec. was found in semi-arid Spanish grasslands (Zabalgogeazcoa et al., 2003). They detected a very high abundance of the fungus in $D$. glomerata, with nine of nine sampled locations being infected. In addition, the rate of infection was also high in F. rubra (70\%) and L. perenne $(47 \%)$. No infection was found in the four samples of $P$. trivialis examined. 
Considering that endophytic fungi are able to enhance the performance of endophyte-infected grasses under drought stress (Arachevaleta, et al. 1989; Malinowski et al., 1997) the high infection frequencies in Iberian grasslands could result from enhanced competitive ability of infected grasses. Lewis et al. (1997) found higher incidences of Neotyphodium Iolii in L. perenne in the Mediterranean regions of France compared to the northern regions. In addition, he discovered a significant positive correlation between the level of endophytic infection and summer drought.

At our study site, the annual precipitation is high (1030 mm) and it is typically not affected by summer drought. This could be a reason for the low infection frequency of the tested grass species. Furthermore, not only drought stress but also grazing pressure of livestock can enhance the rate of infection (Jensen and Roulund, 2004). As our study side was only extensively used as pasture and meadow over a long period of time, there was no selective pressure towards a higher abundance of the endophytic fungus. That circumstance might also have contributed to the low rate of fungal infection. Another reason could be the low nutrient availability of the soil that will be discussed in the following section. 


\section{Treatments}

In contrast to our hypothesis, the composition of the sward did not significantly influence the abundance of Neotyphodium spec. in the four grass species. Several studies have demonstrated an improved competitive ability of endophyte-infected grasses in mixed swards (reviewed in Omacini et al. (2005)). Sutherland and Hoglund (1989) found a decreased survival of white clover (Trifolium repens L.) in endophyte-infected $L$. perenne plots compared to uninfected plots. Similarly, in a four-year field study in Indiana, USA Clay and Holah (1999) investigated the plant species diversity of swards sown with either endophyte-free or endophyte-infected $F$. arundinacea. At the beginning of the experiment, the proportion of $F$. arundinacea in the total biomass averaged $80 \%$ in both infected and uninfected plots. After four years it increased to $90 \%$ in the infected plots and decreased to lower than $60 \%$ in the uninfected plots. Moreover, in the infected plots the plant species diversity was decreased, especially the biomass of the forbs declined $97 \%$ in comparison to $50 \%$ in the uninfected plots. Another study (Clay and Schardl, 2002) indicates that endophyte-free plots are undergoing succession faster than infected plots due to the reduced species diversity in the infected plots. In contrast, Spyreas et al. (2001) found a higher species richness in endophyte-infected, mown plots compared to uninfected. They explained their finding with a reduced competitive ability of drought-stressed tall fescue, which enhanced the survival of other plant species.

Different mechanisms responsible for the enhanced competitive ability of infected grasses in mixed swards were suggested: an improved acquisition of resources, allelophatic properties against other species and an increased tolerance to biotic and abiotic stresses (reviewed in Clay, 1997). In our study, the herbicide application in the Dic- plots should have reduced the interspecific competition for resources and create conditions allowing endophyte-free grasses to propagate. Therefore, we had expected a reduced level of endophytic infection in the Dicplots in comparison to the control plots. In contrast, we did not find any differences in the rate of infection between these plots. A reason for that could be the already low level of endophytic infection in our study area and the unfavorable conditions for endophytic fungi discussed above. 
Contrary to our hypothesis, in this study the cutting frequency did not significantly influence the incidence of Neotyphodium spec. in the four grass species. These findings are in line with results reported in Shelby and Dalrymple (1993). In their four-year field study with $F$. arundinacea they did not find any differences in the incidence of Neotyphodium coenophialum (Morgan-Jones and Gams) Glenn, Bacon and Hanlin between mown and unmown plots. Similarly, Saari et al. (2010) reported that endophytic infection had no influence on the regrowth of meadow fescue (Festuca pratensis Huds.) after clipping in fields older than one year. Although, they detected negative effects of endophytic infection on the regrowth of meadow fescue in a one-year-old field and in short-term greenhouse experiments. In contrast, Spyreas et al. (2001) reported a higher rate of infection in tall fescue in mown rather than in unmown plots. In addition, they measured a decreased soil moisture in mown compared to unmown plots. They concluded that drought stress had enhanced the competitive abilities of endophyte-infected $F$. arundinacea plants in mown plots compared to uninfected plants. In the framework of the interdisciplinary "GrassMan"-project the impact of cutting frequency and fertilization on the water balance of the grassland was examined as well (Rose et al., 2011). Contrary to the results obtained by Spyreas et al. (2001) mowing did not significantly influence the soil moisture of the plots. The evapotranspiration, infiltration, ground water recharge and water use efficiency of the five most abundant plants found in our study area did not differ between plots mown one time or three times a year.

Greenhouse experiments indicate that the effect of cutting frequency can also depend on the grass cultivar (Lewis, 2004). In his experiments, the cutting frequency (every two weeks vs. every 6 weeks) had no influence on the accumulated herbage dry weight of two of three $L$. perenne cultivars. At the final harvest, the mean accumulated herbage dry weight of the third cultivar was significantly higher in endophyte-infected rather than in uninfected grasses. Interestingly, the two grass cultivars that were not influenced by the cutting frequency originated from long established pastures in England, whereas the third cultivar was obtained from New Zealand. Therefore, the results from the European grass cultivars might be better comparable to results from our study. 
In line with our hypothesis, the application of NPK-fertilizer increased the abundance of Neotyphodium spec. in the tested grass species. These findings are consistent with results obtained by Saona et al. (2010). They investigated the abundance of the endophyte of F. rubra across different grazing, nutrient and soil moisture gradients in a boreal archipelago in Sweden. In their study, they found a higher incidence of the endophytic fungus with increasing nutrient availability and decreasing soil moisture. Under mesic - moist conditions the incidence of the endophytic fungus was not influenced by the availability of nutrients. In an additional greenhouse experiment they observed an enhanced competitive ability of infected F. rubra plants under dry, nutrient-rich conditions compared to uninfected plants. Under other conditions tested (low water and nutrients, high water and low nutrients, high water and high nutrients) the uninfected $F$. rubra plants outcompeted the endophyte-infected plants. At our study site Rose et al. (2011) have shown that fertilization significantly increased the above ground biomass and evapotranspiration of the five most abundant plant species (two of them being $D$. glomerata and F. rubra). Moreover, it decreased the infiltration and ground water recharge by $50 \%$ and increased the water use efficiency of the plants by $20-30 \%$. Hence, at our study site fertilization not only increased the availability of soil nutrients but also decreased the soil moisture, creating conditions that favored endophyte-infected plants. Similar results were also obtained from greenhouse experiments with F. rubra (Ahlholm et al., 2002): In fertilized soils endophyte-infected plants produced more biomass than uninfected plants. However, this effect was only measurable in highly watered soil.

An increased performance under nutrient-rich conditions has been demonstrated for other grass species as well. In a field study in Finland Wäli et al. (2008) compared the performance of endophyte-free and infected plants of two cultivars of meadow fescue at two sites with different nutrient status. The performance of endophyte - infected and uninfected fescue plants did not differ at the nutrient poor site. In contrast, at the nutrient-rich site, endophyte-infected plants had significantly more tillers and panicles per plant compared to uninfected plants. However, this was only true for one of the two grass cultivars tested, demonstrating that the endophyte-grass interaction is also genotype-dependent.

An enhanced performance at higher nutrient levels was reported for endophyte infected $L$. perenne and F. arundinacea as well. Moreover, the biomass of infected 
F. arundinacea plants even decreased in nutrient-poor soil in comparison to uninfected plants (Cheplick et al., 1989). They explained their finding with a tradeoff between the benefits of endophytic infection and the metabolic costs to the host. At low nutrient levels, a competition for nutrients between the host plant and the endophyte might occur that would reduce the host's fitness and favor uninfected plants. Therefore, the benefits of endophytic fungi to the host might be better detectable under nutrient-rich conditions although contrasting results for $L$. perenne were obtained as well (Lewis, 2004).

Furthermore, it has been shown that the production of the herbivore-deterrent ergot alkaloids in tall fescue increases in response to $\mathrm{N}$-fertilization (Arachevaleta et al., 1992). Lehtonen et al. (2005) reported a reduced performance of the bird cherry oat aphid (Rhopalosiphum padi L.) with increasing soil-nutrient availability under greenhouse conditions. Therefore, it is likely that in our study fertilization not only reduced the competition for nutrients between the host-plant and the endophyte. Moreover, it might have also shifted the host-endophyte interaction from antagonistic to mutualistic through the endophyte-mediated enhanced resistance to drought and insect herbivores. Subsequently, the increased performance of the grass host resulted in a higher proportion of endophyteinfected grasses in fertilized plots compared to the nutrient-poor plots.

In conclusion, our results show that the abundance of endophytic fungi in grasses is very low under nutrient-poor, mesic-moist conditions. That indicates that such conditions favor uninfected plants and that in this case, the endopyte-host association is rather antagonistic. In line with our hypothesis, we have demonstrated that fertilizer application increased the level of infection compared to unfertilized plots and created conditions favoring endophytes. In contrast, the mowing frequency and the herbicide application had no effect on the abundance of the endophytic fungus.

\section{ACKNOWLEDGEMENTS}

We thank Isabella Herwig for technical assistance with the grass samples and Lars Köhler for coordination of the "GrassMan"-Experiment. We are grateful to Christoph Scherber for his advice on the statistical analysis and Mike Dobrindt for 
reviews and suggestions. This study was funded by the Ministry of Science and Culture of Lower Saxony and the 'Niedersächsisches Vorab'. It is part of the Cluster of Excellence 'Functional Biodiversity Research'. 


\section{REFERENCES}

Ahlholm J. U., Helander M., Lehtimäkı S., Wäli P. and Saikkonen K. (2002) Vertically transmitted fungal endophytes: Different responses of hostparasite systems to environmental conditions. Oikos, 99, 173-183.

Arachevaleta M., Bacon C. W., Hoveland C. S. and RadCliffe D. E. (1989) Effect of the tall fescue endophyte on plant response to environmental stress. Agronomy Journal, 81, 83-90.

Arachevaleta M., Bacon C. W., Plattner R. D., Hoveland C. S. and Radcliffe D. E. (1992) Accumulation of ergopeptide alkaloids in symbiotic tall fescue grown under deficits of soil water and nitrogen fertilizer Applied and Environmental Microbiology, 58, 857-861.

Arnold A. E., Maynard Z., Gilbert G. S., Coley P. D. and Kursar T. A. (2000) Are tropical fungal endophytes hyperdiverse? Ecology Letters, 3, 267-274.

Bacon C. W., Porter J. K., Robbins J. D. and Luttrell E. S. (1977) Epichloetyphina from toxic tall fescue grasses. Applied and Environmental Microbiology, 34, 576-581.

BATES D. and MAECHLER M. (2009) Lme4: Linear mixed-effects models using s4 classes.

Bazely D. R., Ball J. P., Vicari M., Tanentzap A. J., Bérenger M., Rakocevic T. and $\mathrm{KOH}$ S. (2007) Broad-scale geographic patterns in the distribution of vertically-transmitted, asexual endophytes in four naturally-occurring grasses in sweden. Ecography, 30, 367-374.

Breen J. P. (1994) Acremonium endophyte interactions with enhanced plant resistance to insects. Annual Review of Entomology, 39, 401.

BUSH L. P., WILKINSON H. H. and SCHARDL C. L. (1997) Bioprotective alkaloids of grass-fungal endophyte symbioses. Plant physiology, 114, 1.

ChePLICK G. P., CLAY K. and MARKS S. (1989) Interactions between infection by endophytic fungi and nutrient limitation in the grasses lolium perenne and festuca arundinacea. New Phytologist, 111, 89-97

CLAY K. (1988) Fungal endophytes of grasses: A defensive mutualism between plants and fungi. Ecology, 69, 10-16. 
CLAY K. (1990) Fungal endophytes of grasses. Annual Review of Ecology and Systematics, 21, 275-297

CLAY K. (1997) Consequences of endophyte-infected grasses on plant biodiversity Neotyphodium/grass interactions, pp. 109-124. New York, USA: Plenum Press.

CLAY K. and HOLAH J. (1999) Fungal endophyte symbiosis and plant diversity in successional fields. Science, 285, 1742-1744.

CLAY K. and SCHARDL C. L. (2002) Evolutionary origins and ecological consequences of endophyte symbiosis with grasses The American Naturalist, 160, S99-S127

FAETH S. H. (2002) Are endophytic fungi defensive plant mutualists? Oikos, 98, 25-36.

Fletcher L. R. and HaRVey I. C. (1981) An association of a lolium endophyte with ryegrass staggers. New Zealand veterinary journal, 29, 185-186.

Gwinn K. D., Fribourg H. A., Waller J. C., Saxton A. M. and Smith M. C. (1998) Changes in neotyphodium coenophialum infestation levels in tall fescue pastures due to different grazing pressures. Crop Science, 38, 201-204.

Hesse U., Schöberlein W., Wittenmayer L., Förster K., Warnstorff K., Diepenbrock W. and Merbach W. (2003) Effects of neotyphodium endophytes on growth, reproduction and drought-stress tolerance of three lolium perenne I. Genotypes. Grass and Forage Science, 58, 407-415.

Jensen A. M. D. and Roulund N. (2004) Occurrence of neotyphodium endophytes in permanent grassland with perennial ryegrass (lolium perenne) in denmark. Agriculture, Ecosystems \& Environment, 104, 419-427.

$\mathrm{KOH}$ S. and HIK D. S. (2007) Herbivory mediates grass-endophyte relationships. Ecology, 88, 2752-2757.

Koh S., Vicari M., Ball J. P., Rakocevic T., Zaheer S., Hik D. S. and Bazely D. R. (2006) Rapid detection of fungal endophytes in grasses for large-scale studies. Functional Ecology, 20, 736-742.

LAtCh G., Hunt W. F. and Musgrave D. R. (1985) Endophytic fungi affect growth of perennial ryegrass. New Zealand Journal of Agricultural Research, 28, 165-168. 
LATCH G. C. M. (1993) Physiological interactions of endophytic fungi and their hosts. Biotic stress tolerance imparted to grasses by endophytes. Agriculture, Ecosystems \& Environment, 44, 143-156.

Lehtonen P., Helander M. and Saikkonen K. (2005) Are endophyte-mediated effects on herbivores conditional on soil nutrients? Oecologia, 142, 38-45.

LeUCHTMANN A. (1993) Systematics, distribution, and host specificity of grass endophytes. Natural Toxins, 1, 150-162.

LEWIS G. C. (2004) Effects of biotic and abiotic stress on the growth of three genotypes of lolium perenne with and without infection by the fungal endophyte neotyphodium lolii. Annals of Applied Biology, 144, 53-63.

Lewis G. C., Ravel C., NaffaA W., Astier C. and Charmet G. (1997) Occurrence of acremonium endophytes in wild populations of lolium spp. In european countries and a relationship between level of infection and climate in france. Annals of Applied Biology, 130, 227-238.

LEYRONAS C. and RAYNAL G. (2001) Presence of neotyphodium-like endophytes in european grasses. Annals of Applied Biology, 139, 119-127.

Malinowski D., Leuchtmann A., Schmidt D. and Nosberger J. (1997) Symbiosis with neotyphodium uncinatum endophyte may increase the competitive ability of meadow fescue. Agronomy Journal, 89, 833-839.

Malinowski D. P. and Belesky D. P. (2000) Adaptations of endophyte-infected cool-season grasses to environmental stresses: Mechanisms of drought and mineral stress tolerance. Crop Science, 40, 923-940.

Novas M. V., Collantes M. and Cabral D. (2007) Environmental effects on grassendophyte associations in the harsh conditions of south patagonia. FEMS Microbiology Ecology, 61, 164-173.

OldENBURG E. (1997) Endophytic fungi and alkaloid production in perennial ryegrass in germany. Grass and Forage Science, 52, 425-431.

Omacini M., Chaneton E. J., Chersa C. M. and Otero P. (2005) A hierarchical framework fo understanding the ecosystem consequences of endophytegrass symbioses Neotyphodium in cool-season grasses, pp. 141-162. Ames, lowa, USA: Blackwell Publishing Professional

Petersen U., Wrage N., L. Köhler, C. Leuschner and Isselstein J. Manipulating the species composition of permanent grasslands - a new approach to biodiversity experiments. Basic and Applied Ecology. 
Rose L., Coners H. and Leuschner C. (2011) Effects of fertilization and cutting frequency on the water balance of a temperate grassland. Ecohydrology, 63.

SaAri S., Helander M., Lehtonen P., Wallius E. and Saikkonen K. (2010) Fungal endophytes reduce regrowth and affect competitiveness of meadow fescue in early succession of pastures. Grass and Forage Science, 65, 287-295.

SABZALIAN M. and MiRLOHI A. (2010) Neotyphodium endophytes trigger salt resistance in tall and meadow fescues. Journal of plant nutrition and soil science, 173, 952-957.

Saikkonen K., Ahlholm J., Helander M., LehtimÄKı S. and NiemeläInen O. (2000) Endophytic fungi in wild and cultivated grasses in finland. Ecography, 23, 360-366.

Saikkonen K., Faeth S. H., Helander M. and Sullivan T. J. (1998) Fungal endophytes: A continuum of interactions with host plants. Annual Review of Ecology and Systematics, 29, 319-343.

Saikkonen K., Lehtonen P., Helander M., Koricheva J. and Faeth S. H. (2006) Model systems in ecology: Dissecting the endophyte-grass literature. Trends in Plant Science, 11, 428-433.

SAIKKONEN K., SAARI S. and HeLANDER M. (2010) Defensive mutualism between plants and endophytic fungi? Fungal Diversity, 41, 101-113.

Saona N. M., Albrectsen B. R., Ericson L. and Bazely D. R. (2010) Environmental stresses mediate endophyte-grass interactions in a boreal archipelago. Journal of Ecology, 98, 470-479.

Shelby R. A. and DALRYMPLE L. W. (1993) Long-term changes of endophyte infection in tall fescue stands. Grass and Forage Science, 48, 356-361.

Spyreas G., GiBson D. J. and MidDleton B. A. (2001) Effects of endophyte infection in tall fescue (festuca arundinacea : Poaceae) on community diversity. International journal of plant sciences, 162, 1237-1245.

SutheRLAND B. L. and Hoglund J. H. (1989) Effect of ryegrass containing the endophyte (acremonium lolii), on the performance of associated white clover and subsequent crops Proceedings of the New Zealand Grassland Association, 50, 265-269. 
The R Development Core Team. (2009) R: A language and environment for statistical computing. Vienna, Austria: $R$ Foundation for Statistical Computing.

Venables W. N. and RIPLey B. D. (2002) Modern applied statistics with s.

Wälı P. R., Helander M., Lehtonen P. and Saikkonen K. (2008) Endophyte infection, nutrient status of the soil and duration of snow cover influence the performance of meadow fescue in sub-artic conditions. Grass and Forage Science, 63, 324-330.

WILSON D. (1995) Endophyte - the evolution of a term, and clarification of its use and definition. Oikos, 73, 274-276.

Zabalgogeazcoa I., De Aldana B. R. V., Ciudad A. G. and Criado B. G. (2003) Fungal endophytes in grasses from semi-arid permanent grasslands of western spain. Grass and Forage Science, 58, 94-97. 


\section{Chapter 3: Influence of grazer species and sward diversity on the abundance of the endophytic fungus Neotyphodium - does plant diversity matter?}

Lana Dobrindt ${ }^{1}$, Mario Cuchillo ${ }^{2}$ and Stefan Vidal ${ }^{1}$

${ }^{1}$ Georg-August-University Göttingen, Department of Crop Science, Agricultural Entomology, Grisebachstrasse 6, 37077 Göttingen, Germany, phone: ++49(0)55139 3733, Email: Idobrin@gwdg.de

${ }^{2}$ Georg-August-University Göttingen, Department of Crop Science, Grassland Science, Von-Siebold-Strasse 8, 37077 Göttingen, Germany.

Corresponding author: S. Vidal, address as above, phone: $+49(0) 551-399744$, fax: +49(0)551-39 12105, Email: svidal@gwdg.de

\section{ABSTRACT}

The specialized endophytic fungus Neotyphodium is common in many temperate grass species. It can enhance its host's resistance to biotic and abiotic stress. The fungus produces toxic alkaloids and can therefore be detrimental to livestock. We hypothesize that grazing by different types of livestock at varying plant diversities influences the abundance of Neotyphodium in the common pasture grasses Festuca pratensis and Lolium perenne. We conducted a field experiment with six treatments and three replications. The treatments were: grazing by sheep, cattle or co-grazing by sheep and cattle with two plant diversity levels: a herbicide-treated low diversity sward and an untreated high diversity sward. After five years, we measured the level of infection and the preference of livestock for both grass species. For $F$. pratensis, we detected a significantly higher level of infestation with Neotyphodium in the co-grazed low diversity plots compared to the plots grazed by sheep. In contrast, in the diverse plots the grazer species did not influence the fungal abundance. No differences were detected for L. perenne. Therefore, we conclude that biodiversity has an impact on the abundance of Neotyphodium in 
some grass species and that co-grazed low diversity pastures could cause a higher risk of toxicoses.

Keywords: Endophytic fungus, pasture management, Lolium perenne, Festuca pratensis, livestock, biodiversity

\section{INTRODUCTION}

Endophytic fungi of the genus Neotyphodium Glenn, Hanlin and Bacon are widespread in many temperate natural grasslands (Leuchtmann, 1993; Saikkonen et al. 2000). Also, forage species common in pastures and meadows such as perennial ryegrass (Lolium perenne L.) are often infected with Neotyphodium (Jensen and Roulund, 2004). Endophytes are known as microorganisms living inside the plant's tissue without causing any visible symptoms of disease (Wilson, 1995). The grass-endophyte symbiosis is often considered as mutualistic (Clay, 1988) but can become antagonistic as well depending on nutrient availability, environmental conditions and host-genotype interactions (Saikkonen et al., 1998; Faeth and Fagan, 2002). Neotyphodium endophytes systemically colonize the aboveground parts of their host. They do not produce spores, but spread vertically through fungal hyphae growing into seeds (Clay, 1990). In addition to the dissemination of the endophyte, the plants' benefits to the fungus include water, shelter and nutrients (Breen, 1994) In return, the fungus is known to enhance the resistance of its host to drought and other environmental stresses and to improve the uptake of water and nutrients (Malinowski and Belesky, 2000). Moreover, endophytic fungi were shown to enhance the tillering, growth and germination rate of their hosts (Latch et al., 1985; Joost, 1995).

Grazing of endophyte-infected pastures can be detrimental to livestock due to various alkaloids produced by the fungus (Bush et al., 1997). Ergovaline produced by Neotyphodium coenophialum (Latch, Christensen and Samuels), Glenn, Bacon and Hanlin, the endophytic fungus of tall fescue (Festuca arundinacea Schreb.), causes a disease known as "fescue toxicosis" (Bacon et al., 1977). The symptoms expressed in cattle suffering from fescue toxicosis are reduced weight gain, lameness due to vasoconstriction and increased body temperature (Belesky and Bacon, 2009). Lolitrem B produced by the endophyte of perennial ryegrass 
Neotyphodium Iolii (Latch, Christensen and Samuels), Glenn, Bacon and Hanlin was found to cause "ryegrass staggers", a nervous disorder in livestock (Fletcher and Harvey, 1981). N. Iolii also produces ergovaline, but in general, the level of lolitrem B found in infected ryegrass is much higher. Therefore, animals having ingested infected ryegrass first show signs of ryegrass staggers before expressing symptoms of fescue toxicosis (Hovermale and Craig, 2001). Other fungal alkaloids such as peramine and lolines are detrimental to insects and act as feeding deterrents. They show a very low activity against mammals (Bush et al. 1997).

Most studies dealing with fescue toxicosis and ryegrass staggers were conducted in the United States and New Zealand due to severe problems caused by endophyte-infected grasses. Contrary, problems with livestock toxicoses in Europe are rare due to more diverse swards diluting the detrimental effects of alkaloids (Zabalgogeazcoa and Bony, 2008). Another reason could be the modest grazing pressure of livestock compared to those found in USA or New Zealand (Malinowski and Belesky, 2006). Grazing pressure has been shown to increase the level of endophytic infection in pastures (Gwinn et al., 1998; Jensen and Roulund, 2004) and in natural grasslands (Granath et al., 2007). Contrary, Saari et al. (2010) found a reduced incidence of endophytic fungi in meadow fescue (Festuca pratensis Huds.) grazed by cattle in comparison to ungrazed control plots.

Since the 1960, an increase in land use intensity, especially high fertilizer input and high stocking rates along with a loss of sward diversity was observed all over Europe (e.g. Klimek et al., 2007; Weibull et al., 2003). Thus, livestock toxicosis could also occur in intensively managed European pastures. The present study was conducted within the framework of the interdisciplinary "BIOMIX"-project at the University of Göttingen. It aims to investigate the impact of livestock species and sward diversity on pasture productivity. The objective of this study was to find out how grazing of cattle, sheep and co-grazing of cattle and sheep at different sward diversities (high or low diversity) influences the abundance of Neotyphodium in the common pasture grasses L. perenne and F. pratensis. Cograzing of cattle and sheep has been shown to increase the liveweight gain of sheep compared to sheep grazing alone due to complementary pasture use (Fraser et al., 2007). However, it is not known how grazing and co-grazing of different species influences the abundance of endophytic fungi. We are also not 
aware of any studies investigating the effect of grazing and livestock selectivity at varying sward diversity on the level of endophytic infection. This knowledge could provide an important insight in the ecology of endophyte-plant-herbivore interactions and help to assess the risk of livestock toxicosis under different management regimes. We hypothesize that grazing of different grazer species at varying plant diversity influences the level of endophytic infection in $L$. perenne and $F$. pratensis mediated via selectivity of grazing livestock.

\section{MATERIALS AND METHODS}

\section{Study area and experimental design}

This study was carried out within the context of the interdisciplinary "BIOMIX"project at the University of Göttingen. This project investigates the impact of grazer species (cattle, sheep or co-grazing of cattle and sheep) and sward diversity (high or low) on grassland productivity. The experimental site, 9 ha of permanent grassland, was located in the Solling Uplands, Lower Saxony, central Germany $\left(51^{\circ} 46^{\prime} 47 \mathrm{~N}, 9^{\circ} 42^{\prime} 11 \mathrm{E}, 180 \mathrm{~m}\right.$ a. s. I. $)$. The mean annual temperature is $8.2^{\circ} \mathrm{C}$ with an annual precipitation of $879 \mathrm{~mm}$ (Deutscher Wetterdienst 1961 - 1990). The vegetation is characterized as a mesotrophic Lolio-Cynosuretum, the soil type is a pelosol with the soil texture being a clayey/silty loam. Before the beginning of the "BIOMIX" - experiment in 2006, the study site was used as a mown pasture for more than 16 years. It was grazed by varying proportions of cattle and sheep and light manure was applied on a regular basis.

The experiment was conducted in a full-factorial block design with three factor levels for grazer species and two factor levels for sward diversity resulting in six treatments. Each treatment was replicated three times on 0.5 ha plot amounting to 18 plots in total. The three replications of the six treatments were arranged in three blocks $(A, B, C)$, which were grazed rotationally (three rotations per grazing season). Within a block, the treatments were randomly allocated to the plots. The low diversity plots were obtained by herbicide application against dicotyledonous plants on half of the plots (Fluroxypyr/Triclopyr) in fall 2006. This led to grass- 
dominated swards (7 species per $9 \mathrm{~m}^{2}$ ) and untreated high diversity control swards with forbs and legumes (14 species per $9 \mathrm{~m}^{2}$ ) (Seither, 2011).

The three factor levels for grazer species were: $C=$ cattle grazing; $S=$ sheep grazing; CS= cattle and sheep co-grazing. In 2010, during the first grazing rotation in May and the second rotation in June cattle (German Simmental) was stocked with 12.1 \pm 0.9 Livestock units ( $L U=500 \mathrm{~kg}$ of animal live weight) per plot and sheep (Black headed and Leine breeds) with 12.7 $\pm 0.7 \mathrm{LU}$. The LU contribution of cattle and sheep was comparable in the co-grazed plots. During the third rotation in September, the herbage production of the swards was lower than in May and June. Therefore, the stocking density per plot was reduced to $8.2 \pm 0.5 \mathrm{LU}$. When the average compressed sward height decreased to $\sim 5 \mathrm{~cm}$, the livestock was moved to the next block (Castle, 1976).

\section{Forage selectivity and Jacobs' selection index}

The intake choices of Festuca pratensis and Lolium perenne were measured during the whole grazing season 2010 (May-October) as follows: The percentage mass of the two target species was assessed visually in five $0.5 \mathrm{~m}^{2}$ subplots per plot. This was done directly before and after a period of three days of grazing on a plot, thus five times per plot and once per block and rotation. The target species were chosen because they were the most abundant ones in the study area. Jacobs' selection index (1974) was used to calculate the intake preference for single target plant species in relation to their proportion in the sward. Selection index $=\mathrm{ci}-\mathrm{ai} / \mathrm{ci}+\mathrm{ai}-2 \mathrm{ci}$ ai; where $\mathrm{ci}=\%$ forage in the diet and $\mathrm{ai}=\%$ forage in the pasture. In this study, ai was evaluated by the difference between the percentage mass of each plant species before and after three days of grazing. The data were transformed to obtain a Gaussian distribution by adding 1 and multiply by 0.5 . The values of forage selection ranged between -1.0 (entirely rejected) to +1.0 (exclusively preferred). 


\section{Sampling}

The sampling was carried out in the middle of August 2010 between the second and third rotation. For this investigation, the most abundant grass species in the study area were chosen: Festuca pratensis and Lolium perenne. Ten tillers of every grass species were randomly collected from different parts of each plot.

Immediately after sampling, the collected plants were labeled and transported to the laboratory in a cool box. Until further investigation they were preserved in nylon bags at $-20^{\circ} \mathrm{C}$.

\section{Detection of Neotyphodium}

The collected plants were examined for the presence of Neotyphodium spec. using the ELISA-based Phytoscreen field tiller kits. The kits were purchased from the company Agrinostics, Watkinsville, GA, USA. These test kits were developed for the detection of Neotyphodium spec. in Festuca arundinacea Schreb. and $L$. perenne. However, the test kits are suitable for the detection of Neotyphodium spec. in many other grass species (Koh et al., 2006). The grass tillers of $F$. pratensis and $L$. perenne were sliced into cross-sections and placed on an immunoblot membrane. The membrane was incubated in a refrigerator over night at $4\left({ }^{\circ} \mathrm{C}\right)$ allowing the fungal proteins to bind on the membrane's surface. The following day, pooled monoclonal antibodies specific to Neotyphodium spec., an enzyme and a chromogen solution were added to the membrane successively. Tillers infected with Neotyphodium spec. produced a pink imprint on the membrane. On the contrary, uninfected tillers showed a light brown-yellow imprint. 


\section{Statistical analysis}

The data of the endophytic infection were analyzed with a general linear model (GLM) with binomial distribution and logit link function. For the analysis the software R version 2.9.2 (R Development Core Team, 2009) was used. Each grass species was analyzed separately. Endophytic infection was taken as the dependent variable and grazer species, diversity of the sward and their interaction as explanatory variables. Also, the combined factor levels of grazer species and sward diversity were also taken as explanatory variables. Additionally, block was modeled as a fixed effect to account for the spatial heterogeneity of the study site. To correct for overdispersion (residual deviance/degrees of freedom >1) the standard errors were multiplied by the square root of the dispersion parameter $\varphi$ and a quasi-GLM was applied. To test for difference between treatments and factor levels linear contrasts from the R-package MASS (Venables and Ripley, 2002) were used. For model validation residuals plotted against predicted values were analyzed graphically.

The data of the forage selectivity were analyzed by ANOVA with the Proc Mixed model of SAS v.9.2 (2009). All factors were taken as fixed effects, whereas block was used as a random effect. Observations made in the same plot were considered as nested. The model applied was:

$Y^{*} i j^{*}={ }^{*} ?^{*}+P D^{*} i^{*}+G T^{*}{ }^{*}+P D^{*}{ }^{*} \times G^{*} \mathrm{ij}^{*}{ }^{*}{ }^{*} \mathrm{eij}^{*}$

where $\mathrm{Y}=$ is the target variable, $?=$ is the overall mean, $\mathrm{PD}=$ plant diversity treatment (diverse vs. grass dominated swards) ${ }^{*} \mathrm{i}^{*}, \mathrm{GT}=$ grazer type (cattle or sheep / mono or co-grazing) ${ }^{*}{ }^{*}$ and $e=$ random experimental error. Multiple comparisons of the means with a significant difference $(P<0.05)$ were performed with Tukey's test using the macro PDMIX612 of SAS (Saxton, 1998).

\section{RESULTS}

The mean infection rate of $L$. perenne with $N$. lolii for all plots was $4.4 \pm 6.2 \%$ ranging from $0 \%$ to $20 \%$. The mean rate of infection for $F$. pratensis was higher $(60.9 \pm 22.3 \%$ (mean $\pm \mathrm{sd}$ ) and ranged from $28.6 \%$ to $100 \%$. Statistical analysis showed that the diversity of the sward did not influence the abundance of $N$. lolii in L. perenne $(\mathrm{SE}=2.658$, $\mathrm{t}-$ value $=-1.343, \mathrm{P}=0.204)$. In addition, neither the grazer species $(\mathrm{SE}=1.349, \mathrm{t}-$ value $=-0.944, \mathrm{P}=0.364)$ nor the interaction of the sward 
diversity and the grazer species $(\mathrm{SE}=1.0265, \mathrm{t}-$ value $=1.254, \mathrm{P}=0.234)$ had any influence on the abundance of the endophytic fungus. Also, the combined factor levels of sward diversity and grazer species (Fig.1) did not affect the incidence of N. Iolii in L. perenne.

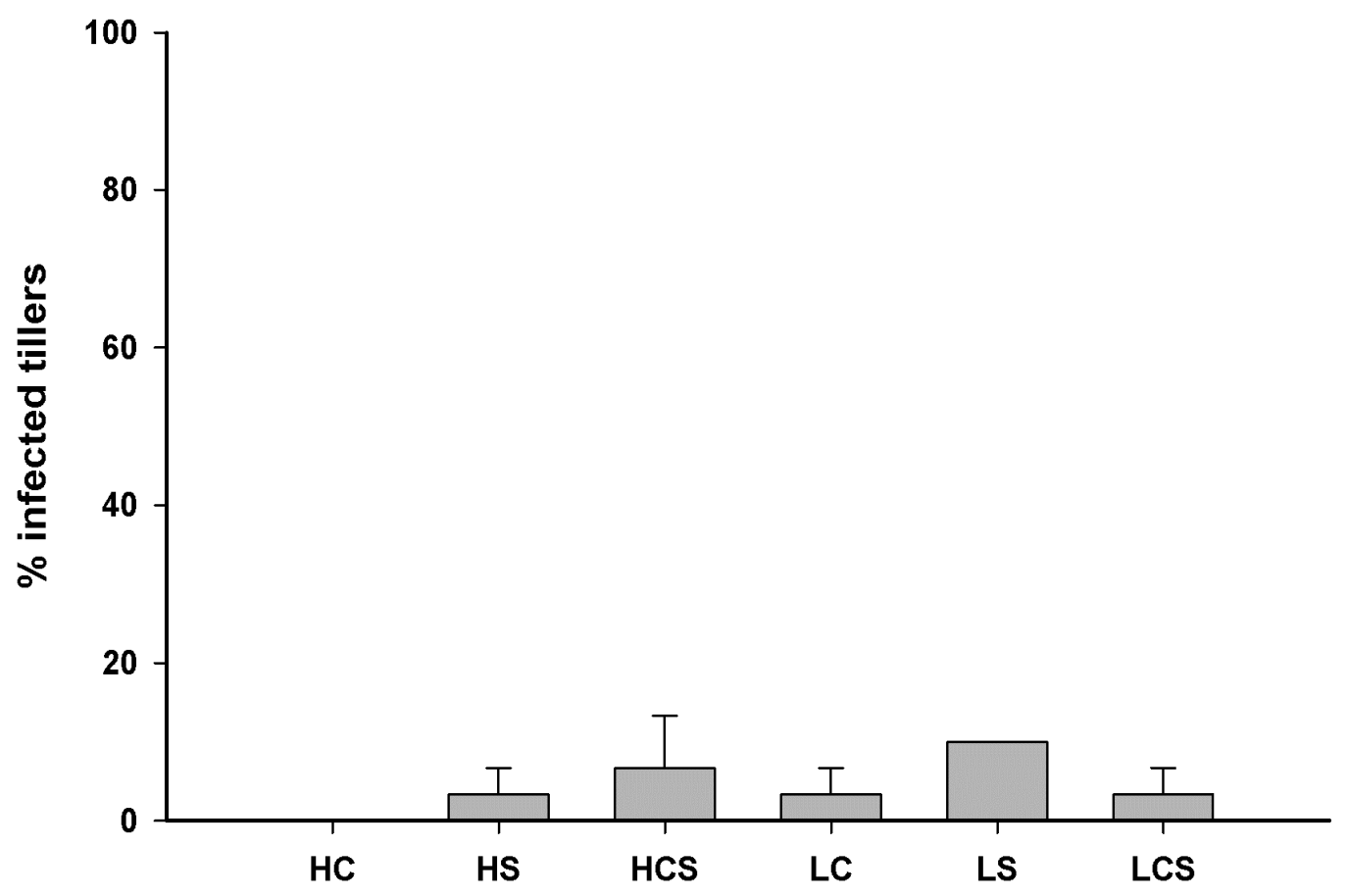

Fig. 1: Percentage of Loium perenne tillers (mean +SE) infected with Neotyphodium lolii at different treatments. Treatments: $\mathrm{HC}=$ high diversity/cattle; $\mathrm{HS}=$ high diversity/sheep ; HCS = high diversity/cattle and sheep; LC = low diversity/cattle; LS = low-diversity/sheep; LCS = low-diversity/cattle.

The sward diversity did not significantly influence the abundance of $N$. unicatum in $F$. pratensis $(\mathrm{SE}=1.190, \mathrm{t}-$ value $=0.847, \mathrm{P}=0.414)$ as well. Also, the grazer species $(\mathrm{SE}=0.889$, $\mathrm{t}$ - value $=1.179, \mathrm{P}=0.261)$ and the interaction of biodiversity and grazer species $(\mathrm{SE}=0.561, \mathrm{t}-$ value $=-0.864, \mathrm{P}=0.405)$ had no impact on the incidence of the fungus. In addition, the grazer species did not influence the abundance of $N$. unicatum in the high diversity plots (Fig. 2). However, in the low diversity plots the grazer species affected the infection rate of the fungus: Plots 
grazed by sheep had significantly lower levels of infection than plots co-grazed by cattle and sheep. The plots grazed by cattle had an intermediate level of infection.

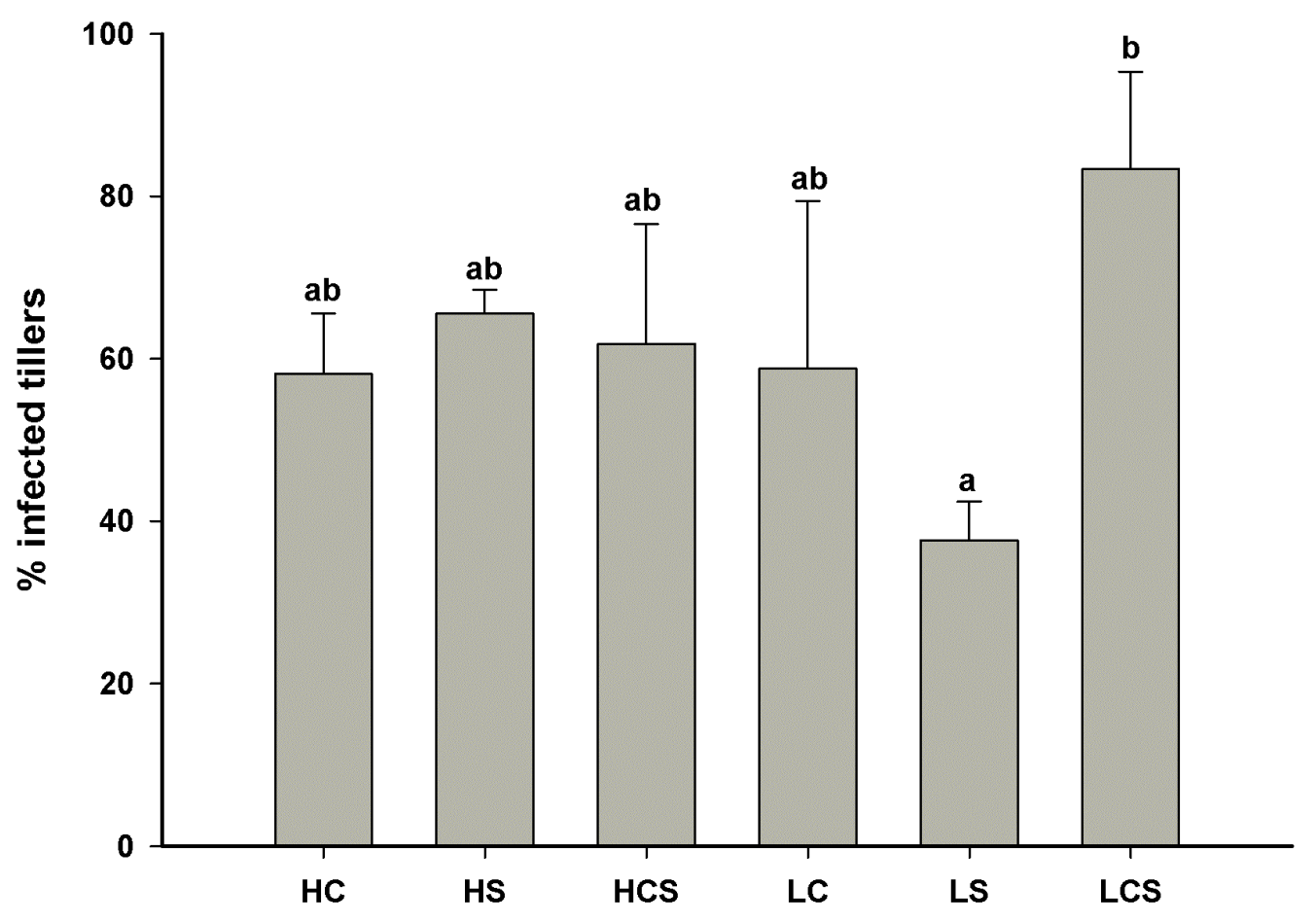

Fig. 2: Percentage of Festuca pratensis tillers (mean +SE) infected with Neotyphodium unicatum at different treatments. Letters above columns indicate significance of difference according to binomial GLM $(P<0.05)$. Treatments: $H C=$ high diversity/cattle; HS = high diversity/sheep; HCS = high diversity/cattle and sheep; LC = low diversity/cattle; LS = low-diversity/sheep; LCS = lowdiversity/cattle and sheep.

The Jacobs' selection index for $L$. perenne shows that this grass species is generally preferred by cattle, sheep and by both grazer species when grazing together. The selection index did not significantly differ between the high diversity and low diversity plots (Tab. 1) and also not between the grazer species. In addition, the combinations of grazer species and sward diversity were not significantly different from each other with regard to the selection index. For F. pratensis, Jacobs' selection index indicates that livestock preferred this grass species in the high diversity plots rather than in the low diversity plots (Tab. 2). In 
addition, it seems that in the low diversity treatment $F$. pratensis was more preferred in the cattle and sheep plots than by sheep alone. However, these trends were statistically not significant.

Tab. 1: Jacobs' selection index (Estimate) for Lolium perenne grazed by cattle, sheep or co-grazed by cattle and sheep at high or low plant sward diversity.

\section{Grazer}

\begin{tabular}{llcl} 
Sward diversity & species & Estimate & \multicolumn{2}{c}{ Std. Error } \\
\hline High & Cattle & $0.5617 \mathrm{a}$ & 0.1751 \\
High & Sheep & $0.6750 \mathrm{a}$ & 0.1751 \\
High & Cattle/Sheep & $0.6084 \mathrm{a}$ & 0.1751 \\
Low & Cattle & $0.4650 \mathrm{a}$ & 0.1751 \\
Low & Sheep & $0.7484 \mathrm{a}$ & 0.1751 \\
Low & Cattle/Sheep & $0.4934 \mathrm{a}$ & 0.1751
\end{tabular}

Cattle= cattle mono-grazing; Sheep= sheep mono-grazing; Cattle/Sheep= co-grazing of cattle and sheep. The Jacobs' selection index ranges between between -1.0 (plant species entirely rejected) to +1.0 (plant species exclusively preferred). Means with different letters indicate significant differences according to ANOVA $(P<0.05)$

Tab. 2: Jacobs' selection index (Estimate) for Festuca pratensis grazed by cattle, sheep or co-grazed by cattle and sheep at high or low plant sward diversity.

\begin{tabular}{llrr}
\hline Sward diversity & Grazer species & \multicolumn{1}{c}{ Estimate } & \multicolumn{1}{c}{ Std. Error } \\
\hline High & Cattle & $0.2699 \mathrm{a}$ & 0.1686 \\
High & Sheep & $0.4632 \mathrm{a}$ & 0.1686 \\
High & Cattle/Sheep & $0.4832 \mathrm{a}$ & 0.1686 \\
Low & Cattle & $0.0849 \mathrm{a}$ & 0.1686 \\
Low & Sheep & $-0.0101 \mathrm{a}$ & 0.1686 \\
Low & Cattle/Sheep & $0.2016 \mathrm{a}$ & 0.1686
\end{tabular}

Cattle= cattle mono-grazing; Sheep= sheep mono-grazing; Cattle/Sheep= cograzing of cattle and sheep. The Jacobs' selection index ranges between between -1.0 (plant species entirely rejected) to +1.0 (plant species exclusively preferred). Different letters indicate significant differences according to ANOVA $(P<0.05)$ 


\section{DISCUSSION}

\section{Level of endophytic infection}

The level of endophytic infection showed much variation within and between the two grass species examined. The mean rate of infection for $L$. perenne was $4.4 \%$ ranging from $0 \%$ to $20 \%$. In contrast, the mean level for infection for $F$. pratensis was much higher (60.9 \%) and ranged from $28.6 \%$ to $100 \%$.

The low incidence of $N$. lolii found in this study is similar to infection levels reported for German grasslands (Oldenburg, 1997). She found a mean infection rate of $13 \%$ for Lower Saxony within the range of $0-50 \%$. For other German regions the mean level of infection was 15 - 28\%. Hesse (2002) found a higher mean incidence of N. Iolii (35\%) in east and central Germany. She reported of a significantly higher abundance of the fungus at dry sites (48\%) compared to periodically wet $(23 \%)$ and wet $(26 \%)$ sites. Comparable results were obtained by Cagaš (1999) who studied the abundance of $L$. perenne in different regions of the Czech Republic. He measured $15 \%$ of the 375 natural L. perenne ecotypes sampled being infected with $N$. Iolii. He also found a relationship between the level of infection and the climatic conditions of the sampled locations: Plants collected from sites with a higher mean annual temperature (above $8^{\circ} \mathrm{C}$ ) and a lower annual rainfall $(500-600 \mathrm{~mm})$ had a higher incidence of infection than plants from cooler and more humid sites. For conditions related to our study site (about $8^{\circ} \mathrm{C}$ mean temperature and $800-900 \mathrm{~mm}$ mean rainfall) he reported of infection levels between $9-10 \%$. Accordingly, endophytic fungi are known to enhance the drought resistance of their hosts in some grass species (Malinowski and Belesky, 2000). Therefore, the high amount of precipitation and the low temperature could be responsible for the low levels of endophytic infection in $L$. perenne found in this study. This corresponds with Zabalgogeazcoa et al. (2003), who found a high incidence of $N$. Iolii (47\%) in semi-arid Spanish grasslands and Lewis et al. (1997), who detected a significant positive correlation between the abundance of $N$. Iolii and summer drought in different regions of France.

The level of endophytic infection in F. pratensis found in this study was similar to those reported in Pfannmöller et al. (1997). In their study, they investigated the 
infection rate of different fescue species from natural grasslands and botanical gardens in Europe. Of the 14 F. pratensis ecotypes tested, 64\% contained endophytic fungi with the level of infestation ranging from $26-100 \%$. Additionally, Jensen et al. (2007) found a high incidence of Neotyphodium in grass habitats from northern Italy with 8 of 8 F. pratensis ecotypes being infected. A comparable level of infection was also found in populations of $F$. pratensis from Finland with a mean incidence of $42 \%$ within the range of $10-100 \%$ (Saikkonen et al., 2000). Moreover, in her study on German grasslands Hesse (2002) detected a higher infection rate of Neotyphodium in F. pratensis at wet sites $(91 \%)$ and periodically wet sites (89\%) in comparison to dry sites (75\%). In contrast, some greenhouse studies indicate that infections with Neotyphodium enhance the performance of $F$. pratensis under drought stress (Malinowski et al., 1997a; Malinowski et al., 1997b). However, those effects could be different under field conditions due to varying environmental influences. Therefore, the ample precipitation at our study site might have favored the high level of endophytic infection in F. pratensis compared to L. perenne.

Contrary to our hypothesis the sward diversity, grazer species and the combination of their factor levels had no influence the abundance of $N$. Iolii in $L$. perenne. Also, Jacobs' selection index was not affected by these factors. Although, the selection index indicated that $L$. perenne was readily consumed by both grazer species. There are several studies showing a relationship between the level of endophytic infection and grazing pressure. For instance, Jensen and Roulund (2004) found a higher incidence of $N$. lolii in L. perenne in grazed compared to ungrazed permanent Danish grasslands. Similarly, the abundance of Neotyphodium in Festuca rubra L. was higher on a Scottish islands intensively grazed by feral sheep in contrast to a neighboring ungrazed island (Bazely et al., 1997). In a grazing experiment with cattle Gwinn et al. (1998) measured a significantly increased infestation of Festuca arundinacea with Neotyphodium coenophialum in response to elevated grazing pressure. This effect was only measurable at intermediate and high but not at low and very high initial levels of endophytic infection. Results obtained by Koh and Hik (2007) could provide a possible explanation for this finding. In a field experiment in Yukon Territory, Canada they measured a higher incidence of Neotyphodium spp. in Festuca altaica Trin. in grass patches heavily grazed by collared pikas (Ochotona collaris). 
In contrast, grass patches with intermediate or no grazing at all had a lower incidence of the fungus. A choice test showed that pikas were capable of discriminating between infected and non-infected grasses at high and intermediate, but not at low levels of endophytic infection. Accordingly, the level of endophytic infection in our study was very low. Although cattle and sheep prefer uninfected to infected grasses (Van Santen, 1992; Cosgrove et al., 2002) the low level of infection might have confounded this ability. In addition, the intake of other plant species might have further diluted the detrimental effects of fungal alkaloids thus further reducing the need to avoid infected perennial ryegrass. These results are also consistent with the finding that endophyte populations are relatively stable at low $(<10 \%)$ and high $(>60 \%)$ initial endophyte levels. In contrast, populations with moderate initial infection (10-60\%) showed the highest rate of increase (Hume and Barker, 2005).

\section{Treatments}

Contrary to the infection rate of $L$. perenne, the level of endophytic infection in $F$. pratensis was high and showed much variation. The sward diversity, grazer species and their interaction had no effect on the abundance of the fungus. Also, the infection rate did not differ between the grazer species in the high diversity swards. In contrast, in the grass-dominated plots the level of infection was significantly higher in plots co-grazed by cattle and sheep compared to plots grazed by sheep only. The treatments, their interaction and the combined factor levels of grazer species and sward diversity did not significantly influence Jacobs' selection index. Although not significant, there was a trend indicating that $F$. pratensis was rather preferred in the high diversity than in the low diversity treatment. In the low diversity plots, F. pratensis was most preferred in the cograzed plots, followed by cattle and then by sheep. As mentioned above, grazing pressure can increase the level of endophytic infection mediated via production of toxic alkaloids (ergovaline and lolitrem B) thus favoring infected plants (Gwinn et al., 1998). Although, contradictory results were obtained by Saari et al. (2010), who found a reduced infection rate in meadow fescue plots grazed by cattle compared to ungrazed plots. However, it is not clear if $N$. unicatum, the endophyte 
of $F$. pratensis, is toxic to livestock. As reviewed in Bush et al. (1997), F. pratensis only produces loline alkaloids, which are not known to cause livestock toxicosis. Accordingly, Jensen et al. (2007) did not measure any ergovaline in six endophyte-infected $F$. pratensis ecotypes from northern Italy. In contrast, Cagaš et al. (1999) detected ergovaline in 17 of 19 infected $F$. pratensis ecotypes collected in different regions of the Czech Republic. The level of ergovaline varied with season being highest in May and August and lowest in October. The mean level of ergovaline was above the critical value at which clinical signs in livestock typically occur (> 300-400 ppb (Hovermale and Craig, 2001)) at four of the six sampling dates.

In our study, we did not measure the level of ergovaline. However, it is feasible that ergovaline was present in meadow fescue infected with the fungus. In the high diversity plots, the grazing pressure of sheep was quite high as indicated by Jacobs' selection index. In contrast, sheep did not prefer F. pratensis in the grassdominated swards. That might have led to the reduced level of infection in those plots compared to the diverse plots. Villalba et al. (2011) showed that plant's secondary compounds influence the foraging behavior of sheep. For instance, sheep given intraruminal administrations of ergotamine preferred herbs, which contained saponins and tannins and avoided tall fescue containing ergovaline. They concluded that sheep used herbs to detoxify ergotamine and rejected tall fescue to avoid over-ingesting ergovaline.

Applied to our study, sheep grazing $F$. pratensis in the diverse sward could have had more possibilities to detoxify potential alkaloids thus being able to tolerate higher levels of infection. In the grass-dominated swards, the lack of legumes and forbs could have caused the reduced preference for $F$. pratensis leading to a lower level of infection. Similarly, cattle seemed to prefer $F$. pratensis in the diverse plots slightly more than in the grass-dominated plots. In the grass-dominated plots, $F$. pratensis was most preferred in the co-grazed plots although it exhibited the highest level of endophytic infection and was not favored by cattle or sheep grazing alone. The reason for that could be that sheep are more selective in their forage behavior than cattle (reviewed in Rook et al., 2004) because of their body size and their narrow mouths. Therefore, sheep are more likely to consume more palatable high quality forage leaving the less digestible food to the cattle (Nicol et al., 2005). This could have also been the case with infected F. pratensis in our 
study. In the grass dominated treatment, the higher preference of $F$. pratensis in the co-grazed plot compared to plots grazed by sheep alone, could have caused the significant difference in endophytic infection between these treatments.

However, F. pratensis was even more preferred in the co-grazed high diversity plots than in the co-grazed grass-dominated plots, although the level of infection in the grass-dominated plots was higher. Considering the present data, it seems that differences in grazing pressure, expressed as Jacobs' selection index, have a stronger impact in the grass-dominated swards compared to the high diversity plots. The reason for this is not obvious and could be caused by some mechanism buffering the effect of grazing pressure on endophyte infection in the high diversity swards. Currently, there is a lack of studies dealing with the impact of co-grazing on the abundance of endophytic fungi under different diversity regimes. Hence, we cannot compare our results to other studies in order to explain this observation. Possible future studies should therefore investigate the effect of sward diversity and grazing pressure on the level of endophytic infection and its implications for grassland management practices. Our results indicate that co-grazing of cattle and sheep in grass-dominated, low diversity swards can increase the level of endophytic infection resulting in a higher risk of livestock toxicosis. In contrast, this effect did not occur in high diversity plots with a high abundance of herbs and legumes.

\section{CONCLUSIONS}

In the present study we found a low abundance of N. lolii in L. perenne contrary to the high abundance of $N$. unicatum in F. pratensis. Jacobs' selection index indicates that $L$. perenne was readily consumed in all treatments. However contrary to our hypothesis, the treatments and their interaction did not influence the abundance of $\mathrm{N}$. Iolii. The reason for that could be the low rate of infection in $L$. perenne, which confounded the ability of livestock to discriminate between infected and uninfected grasses. Similarly, the grazer species did not influence the abundance of $N$. unicatum in the high diversity plots. In contrast, the abundance of the fungus was significantly lower in plots grazed by sheep than in the plots cograzed by cattle and sheep in the grass-dominated low diversity plots. These 
results indicate that co-grazing of cattle and sheep in swards with low plant species diversity enhances the infection rate of $N$. unicatum and elevates the risk of livestock toxicoses in comparison to diverse swards.

\section{ACKNOWLEDGEMENTS}

We thank Christoph Scherber for his support with the statistical analysis and the staff of the experimental farm in Relliehausen (Georg-August University of Göttingen) for their cooperation. We are also grateful to Isabella Herwig for her technical assistance with the grass samples. This study is part of the Cluster of Excellence 'Functional Biodiversity Research' funded by the Ministry of Science and Culture of Lower Saxony and the 'Niedersächsisches Vorab'. 


\section{REFERENCES}

Bacon C.W., Porter J.K., Robbins J.D. and LutTRell E.S. (1977) Epichloetyphina from toxic tall fescue grasses. Applied and Environmental Microbiology, 34, 576-581.

Bazely D.R., VICARI M., EMmerICH S., FILIP L., LIN D. and INMAN A. (1997) Interactions between Herbivores and Endophyte-Infected Festuca rubra from the Scottish Islands of St. Kilda, Benbecula and Rum. Journal of applied ecology, 34, 847-860.

BELESKY D.P. and BACON C.W. (2009) Tall fescue and associated mutualistic toxic fungal endophytes in agroecosystems. Toxin Reviews, 28, 102-117.

BREEN J.P. (1994) Acremonium endophyte interactions with enhanced plant resistance to insects. Annual Review of Entomology, 39, 401.

BUSH L.P., WILKINSON H.H. and SCHARDL C.L. (1997) Bioprotective alkaloids of grass-fungal endophyte symbioses. Plant physiology, 114, 1.

CAgAŠ B., Flieger M. and OlšovskÁ J. (1999) Concentration of ergot alkaloids in Czech ecotypes of Lolium perenne and Festuca pratensis. Grass and Forage Science, 54, 365-370.

CASTLE, M.E. (1976) A simple disc instrument for estimating herbage yield. Journal of the British Grassland Society, 31, 37-40.

CLAY K. (1988) Fungal endophytes of grasses: A defensive mutualism between plants and fungi. Ecology, 69, 10-16.

CLAY K. (1990) Fungal endophytes of grasses. Annual Review of Ecology and Systematics, 21, 275-297.

Cosgrove G.P., Anderson C.B., Phillot M., Nyfeler D., Hume D.E., Parsons A.J. and LANE G.A. (2002) The effect of endophyte alkaloids on diet selection by sheep. Proceedings of the New Zealand Society of Animal Production, 62, 167-170.

FAETH S.H. (2002) Are endophytic fungi defensive plant mutualists? Oikos, 98, 2536.

FLETCHER L.R. and HARVEY I.C. (1981) An association of a lolium endophyte with ryegrass staggers. New Zealand veterinary journal, 29, 185-186.

Fraser M.D., DaVies D.A., Vale J.E., HiRst W.M. and Wright I.A. (2007) Effects on animal performance and sward composition of mixed and sequential 
grazing of permanent pasture by cattle and sheep. Livestock Science, 110, 251-266.

Granath G., Vicari M., Bazely D.R., Ball J.P., Puentes A. and Rakocivic T. (2007) Variation in the abundance of fungal endophytes in fescue grasses along altitudinal and grazing gradients. Ecography, 30, 422-430.

Gwinn K.D., Fribourg H.A., Waller J.C., SAXton A.M. and Smith M.C. (1998) Changes in neotyphodium coenophialum infestation levels in tall fescue pastures due to different grazing pressures. Crop Science, 38, 201-204.

HESSE U. (2002) Untersuchungen zur Endophytbesiedelung von Gräserökotypen und zu Symbioseeffekten durch Neotyphodium lolii in Lolium perenneGenotypen hinsichtlich Stresstoleranz und Ertragsmerkmale. Diss. MartinLuther-Universität Halle-Wittenberg.

Hovermale J.T. and Craig A.M. (2001) Correlation of ergovaline and lolitrem B levels in endophyte-infected perennial ryegrass (Lolium perenne). Journal of Veterinary Diagnostic Investigation, 13, 323-327.

HUME D.E. and BARKER D.J. (2005) Growth and management of endophytic grasses in pastoral agriculture. In: Roberts C.A., West, C.P. and Spiers D.E (eds.) Neotyphodium in cool-season grasses. Blackwell Publishing Ltd., Ames, lowa, USA, 2005, 23-33.

JENSEN A.M.D. and RouLUND N. (2004) Occurrence of neotyphodium endophytes in permanent grassland with perennial ryegrass (lolium perenne) in denmark. Agriculture, Ecosystems \& Environment, 104, 419-427.

Jensen A.M.D., MikKelsen L. and Roulund N. (2004) Variation in genetic markers and ergovaline production in endophyte (Neotyphodium)-infected fescue species collected in Italy, Spain, and Denmark. Crop Science, 47, 139-147.

Joost R.E. (1995) Acremonium in fescue and ryegrass: boon or bane? A review. Journal of Animal Science, 73, 881-888.

Klimek S., Richter G., Kemmermann A., Hofman M. and Isselstein J. (2007) Plant species richness and composition in managed grasslands: The relative importance of field management and environmental factors. Biological Conservation, 134, 559-570.

$\mathrm{KOH}$ S. and HIK D.S. (2007) Herbivory mediates grass-endophyte relationships. Ecology, 88, 2752-2757. 
Koh S., Vicari M., Ball J.P., Rakocevic T., Zaheer S., Hik D.S. and Bazely D.R. (2006) Rapid detection of fungal endophytes in grasses for large-scale studies. Functional Ecology, 20, 736-742.

LATCH G., HUNT W.F. and MusGRAVE D.R. (1985) Endophytic fungi affect growth of perennial ryegrass. New Zealand Journal of Agricultural Research, 28, 165168.

LEUCHTMANN A. (1993) Systematics, distribution, and host specificity of grass endophytes. Natural Toxins, 1, 150-162.

Lewis G.C., Ravel C., NaffaA W., Astier C. and Charmet G. (1997) Occurrence of acremonium endophytes in wild populations of lolium spp. In european countries and a relationship between level of infection and climate in france. Annals of Applied Biology, 130, 227-238.

MALINOWSKI D.P. and BELESKY D.P. (2000) Adaptations of endophyte-infected coolseason grasses to environmental stresses: Mechanisms of drought and mineral stress tolerance. Crop Science, 40, 923-940.

MALINOWSKI D.P. and BELESKY D.P. (2006) Ecological importance of Neotyphodium spp. grass endophytes in agroecosystems. Grassland science, 52, 1.

Malinowski D., Leuchtmann A., Schmidt D. and Nösberger J. (1997a) Symbiosis with neotyphodium uncinatum endophyte may increase the competitive ability of meadow fescue. Agronomy Journal, 89, 833-839.

Malinowski D., Leuchtmann A., Schmidt D. and Nösberger J. (1997b) Growth and water status in meadow fescue is affected by Neotyphodium and Phialophora species endophytes. Agronomy Journal, 89, 673-678.

Nicol A.M., Soper M.B. and SteWARD A. (2005) Diversity of diet composition decreases with conjoint grazing of cattle with sheep and goats. $X X$ International Grassland Congress, 498.

OldenbuRg E. (1997) Endophytic fungi and alkaloid production in perennial ryegrass in germany. Grass and Forage Science, 52, 425-431.

Pfannmöller M., Eggestein S. and SchÖbeRlein W. (1997) Occurence of endophytes in european cultivars, seed lots, and ecotypes of Festuca species. In: Bacon C.W. and Hill N.S. (eds.) Neotyphodium/Grass interactions. Plenum Press, New York, 1997, 77-80. 
The R Development Core Team. (2009) R: A language and environment for statistical computing. Vienna, Austria: R Foundation for Statistical Computing.

Rook A.J., Dumont B., ISselstein J., Osoro K., WallisDeVRies M.F., PARENTE G. and MILLS J. (2004) Matching type of lifestock to desired biodiversity outcomes in pastures - a review. Biological conservation, 119, 137-150.

SaAri S., Helander M., Lehtonen P., Wallius E. and Saikkonen K. (2010) Fungal endophytes reduce regrowth and affect competitiveness of meadow fescue in early succession of pastures. Grass and Forage Science, 65, 287-295.

SaikKonen K., FAeth S. H., Helander M. and Sullivan T.J. (1998) Fungal endophytes: A continuum of interactions with host plants. Annual Review of Ecology and Systematics, 29, 319-343.

Saikkonen K., Ahlholm J., Helander M., LehtimÄKı S. and NiemeläInen O. (2000) Endophytic fungi in wild and cultivated grasses in finland. Ecography, 23, 360-366.

SAS (2009) *SAS/STAT® 9.2. User's Guide. Second edition*. SAS. Institute Inc., Cary, North Carolina, USA.

SAXTON A.M. (1998) A macro for converting mean separation output to letter groupings in Proc Mixed. In: *Proc. 23rd SAS Users Group Intl. *, Nashville, TN., SAS Institute, Cary, NC., 1243-1246.

SEITHER M. (2011) The effect of grassland botanical composition and (co-) grazing cattle and sheep on herbage production and sward nutrient utilisation. Diss., Cuvelier Verlag, Göttingen, Germany.

VAN SANTEN E. (1992) Animal preference of tall fescue during reproductive growth in the spring. Agronomy journal, 84, 979.

VENABLES W.N. and RIPLEY B.D. (2002) Modern applied statistics with s.

Villalba J.J., Provenza F.D., Clemensen A.K., Larsen R. and JuhnKe J. (2011) Preference for diverse pastures by sheep in response to intraruminal administrations of tannins, saponins and alkaloids. Grass and Forage Science, 66, 224-236.

Weibull A.-C., Östman Ö. and GranqVist A. (2003) Species richness in agroecosystems: the effect of landscape, habitat and farm management. Biodiversity and Conservation, 12, 1335-1355. 
WILSON D. (1995) Endophyte - the evolution of a term, and clarification of its use and definition. Oikos, 73, 274-276.

ZabalgogeazcoA I. and Bony S. (2008). Neotyphodium Research and Application in Europe. In: Roberts C.A., West, C.P. and Spiers D.E (eds.) Neotyphodium in cool-season grasses. Blackwell Publishing Ltd., Ames, lowa, USA, 2005, 23-33.

Zabalgogeazcoa I., De Aldana B.R.V., Ciudad A.G. and Criado B.G. (2003) Fungal endophytes in grasses from semi-arid permanent grasslands of western spain. Grass and Forage Science, 58, 94-97. 


\section{General Discussion}

Endophytic fungi of the genus Neotyphodium have been found in many temperate grass species examined (Leuchtmann, 1993; Zabalgogeazcoa et al., 2003). Lewis et al. (1997) detected Lolium spec. plants infected with Neotyphodium Iolii in 15 of 20 European countries. In the warmer regions of France such as Corsica and other Mediterranean regions they found a higher abundance of the fungus in comparison to the northern regions. In addition, they discovered a significant positive correlation between the level of endophytic infection and summer drought. Also, Zabalgogeazcoa et al. (2003) found a high infection rate $(47 \%)$ of $N$. lolii in Spanish permanent grasslands whereas Oldenburg (1997) found a low level of infection in several German regions. Accordingly, Arachevaleta et al. (1989) have shown that endophyte-infected grasses have an enhanced performance under drought stress compared to their uninfected conspecifics.

Those findings correspond with our results. In the 90 agriculturally utilized grasslands which we have examined in our study, we have found a low mean level of endophytic infection (6\%) in L. perenne under the mesic-moist conditions of the rural district of Northeim, central Germany. Also, we found a low infection rate in $L$. perenne, Festuca rubra and Dactylis glomerata in our experimental permanent grassland in the Solling Uplands, central Germany. Accordingly, this area also has a very high level of precipitation.

On the other hand, we have found a high abundance of $L$. perenne infected with $N$. Iolii on sites with limestone bedrock compared to sites with other bedrock like sandstone, loess or solifluction soil in the rural district of Northeim. In addition, sites with limestock bedrock had significantly higher levels of potassium in comparison to other sites. As limestone has a poor water holding capacity, plants growing on those sites are more likely to suffer from drought stress. Although the rural district of Northeim is generally not affected by drought stress, temporal summer drought can occur at those sites.

It has been shown that endophyte-infected grasses have an increased potassium uptake (Khayamim et al., 2010) in comparison to uninfected grasses. Similarly, Bayat et al. (2009) found higher contents of potassium in the shoots of infected Festuca arundinacea under drought stress and a significantly higher survival of 
infected plants after stress removal. They concluded that potassium could be of great importance for osmotic adjustment and stomatal conductance of droughtstressed plants. Therfore, the low water holding capacity of sites with limestone bedrock and the enhanced availability of $\mathrm{K}$ at those sites could have contributed to the propagation of infected $L$. perenne plants in our study. To our knowledge this is the first study showing an influence of geology on the incidence of Neotyphodium.

In the rural district of Northeim, we have also examined the impact of grassland management on the abundance of $N$. Iolii in L. perenne. We had hypothesized that more intensively managed grassland should experience higher incidences of $N$. Iolii and that grasslands used as pastures, mown pastures or meadows should differ in their rate of infection. In contrast to our hypothesis, neither the different levels of land use intensity (extensive, intermediate, intensive) nor the type of land use (meadows, mown pastures, pastures) had any significant impact on the abundance of $N$. Iolii.

Several studies had shown that grazing pressure increases the level of endophytic infection and that grazing livestock is able to disciminate between infected and uninfected grasses (Van Santen, 1992; Gwinn et al., 1998; Jensen and Roulund, 2004). It has been also shown that herbivores are not able to detect low levels of endophytic infection and that the level of infection does not increase in pastures with a low initial infection rate (Gwinn et al., 1998, Koh and Hik, 2007). Therefore, the low infection levels at our sites may have prevented the discrimination ability of cattle in the present study. In addition, the high number of other plant species within the fields investigated might have further reduced uptake of high levels of alkaloids produced by Neotyphodium. This could have additionally reduced the pressure on the cattle to discriminate between infected and non-infected grass tillers. These results indicate that the risk of livestock toxicoses in central Germany is low.

In this study the mowing frequency had no influence on the infection rate of Neotyphodium. This finding corresponds to Shelby and Dalrymple (1993) who did not find any significant differences in the infection rate of tall fescue between mown and unmown plots in a four-year field study. 
Moreover, in another study the mowing frequency (once a year vs. three times a year) did not influence the abundance of Neotyphodium in our experimental "GrassMan" meadow in the Solling Uplands. Also, the composition of the sward (diverse vs. grass-dominated low diversity sward) had no impact on the level of endophytic infection. In contrast, application of fertilizer (NPK) significantly increased the abundance of Neotyphodium in the four grass species examined compared to the control plots.

These findings are in line with results obtained by Saona et al. (2010). They investigated the incidence of Neotyphodium in F. rubra across a nutrient gradient in a boreal archipelago in Sweden. In their study they found a higher abundance of the endophytic fungus with increasing nutrient availability. Additionally, in a greenhouse study Cheplick et al. (1989) found an enhanced performance of endophyte-infected $L$. perenne and Festuca arundinacea Schreb. under nutrientrich conditions compared to uninfected plants. In contrast, the biomass of infected $F$. arundinacea plants decreased in nutrient-poor soil in comparison to uninfected plants. They explained their finding with a trade-off between the benefits of endophytic infection and the metabolic costs to the host. At low nutrient levels, a competition for nutrients between the grass and the endophyte might occur. This competition would reduce the host's fitness and favor uninfected plants. It is therefore likely that the benefits of endophytes are better detectable under nutrient-rich conditions. Also in our study, fertilization might have reduced the competition for nutrients between the host-plant and the endophyte and shifted the host-endophyte interaction from antagonistic to mutualistic resulting in a higher incidence of infected plants.

Many studies dealing with the effect of nutrients on endophytic fungi were carried out in either sown, experimental fields or were surveys of naturally occurring grasslands. In this study we have demonstated the benefitial effects of nutrients in an old, permanent grassland. Therefore, our results might be better applicable to agriculturally utilized grasslands.

In the third study, we have examined the impact of different grazer species (grazing by cattle, sheep and co-grazing of cattle and sheep) under different diversity regimes (high and low sward diversity) on the abundance of Neotyphodium spec. in L. perenne and Festuca pratensis (meadow fescue). This investigation was carried out in an experimental pasture in the Solling Uplands, 
central Germany. We found a very low mean abundance of Neotyphodium in $L$. perenne (about $4 \%$ ) and a high abundance of the fungus in F. pratensis (over $60 \%)$.

In the high diversity treatment grazing and co-grazing of cattle and sheep had no influence on the abundance of the fungus in both grass species. In the low diversity treatment the incidence of Neotyphodium unicatum in F. pratensis was significantly higher in plots co-grazed by cattle and sheep compared to plots grazed by sheep only. In contrast, there was no difference in the abundance of $N$. Iolii in L. perenne between the grazing treatments. We are not aware of any studies dealing with the impact of grazing and co-grazing of different livestock species under varying sward diversities on the abundance of endophytic fungi. Therefore, it is difficult to compare the results of this study to other studies. Further studies in this area could provide valuable insight in the ecology of endophytegrass-herbivore interactions and help to optimize management strategies in order to reduce the risk of livestock toxicoses. 


\section{References cited in general introduction and discussion}

Ahlholm J.U., Helander M., LehtimäKı S., WÄlı P. and SAiKKonen K. (2002) Vertically transmitted fungal endophytes: Different responses of hostparasite systems to environmental conditions. Oikos, 99, 173-183.

Arachevaleta M., Bacon C.W., Hoveland C.S. and RadCliffe D.E. (1989) Effect of the tall fescue endophyte on plant response to environmental stress. Agronomy Journal, 81, 83-90.

Bacon C.W., Porter J.K., RobBins J.D. and LutTRELl E.S. (1977) Epichloetyphina from toxic tall fescue grasses. Applied and Environmental Microbiology, 34, 576-581.

Bayat F., Mirlohi A. and KhOdambashi M. (2009) Effects of endophytic fungi on some drought tolerance mechanisms of tall fescue in a hydroponics culture. Russian Journal of Plant Physiology, 56, 510-516.

BELESKY D.P. and BACON C.W. (2009) Tall fescue and associated mutualistic toxic fungal endophytes in agroecosystems. Toxin Reviews, 28, 102-117.

BREEN J.P. (1994) Acremonium endophyte interactions with enhanced plant resistance to insects. Annual Review of Entomology, 39, 401.

BUSH L.P., WILKINSON H.H. and SCHARDL C.L. (1997) Bioprotective alkaloids of grass-fungal endophyte symbioses. Plant physiology, 114, 1.

CARlier L., Rotar I., Vlahova M. and VidicAN R. (2009) Importance and functions of grasslands. Notulae Botanicae Horti Agrobotanici Cluj-Napoca, 37, 2530.

ChEPLICK G.P., CLAY K. and MARKS S. (1989) Interactions between infection by endophytic fungi and nutrient limitation in the grasses lolium perenne and festuca arundinacea. New Phytologist, 111, 89-97

CLAY K. (1988) Fungal endophytes of grasses: A defensive mutualism between plants and fungi. Ecology, 69, 10-16.

CLAY K. and SCHARDL C.L. (2002) Evolutionary origins and ecological consequences of endophyte symbiosis with grasses. The American Naturalist, 160, 99-127

Conover M.R. and Messmer T.A. (1996) Feeding preferences and changes in mass of Canada geese grazing endophyte-infected tall fescue. Condor, 98, 859-862. 
FLETCHER L.R. and HARVEY I.C. (1981) An association of a lolium endophyte with ryegrass staggers. New Zealand veterinary journal, 29, 185-186.

GWinn K.D., Fribourg H.A., Waller J.C., SAxton A.M. and Smith M.C. (1998) Changes in neotyphodium coenophialum infestation levels in tall fescue pastures due to different grazing pressures. Crop Science, 38, 201-204.

Hesse U., Hahn H., Andreeva K., Forster K., Warnstorff K., Schoberlein W. and DiEPENBROCK W. (2004) Investigations on the influence of Neotyphodium endophytes on plant growth and seed yield of Lolium perenne genotypes. Crop Science, 44, 1689-1695.

HOVELAND C.S. (1997) Introduction: Welcome and a bit of endophyte history. In: Bacon C.W. and Hill N.S. (eds.) Neotyphodium/Grass interactions. Plenum Press, New York, 1997, XV-XVII.

Hovermale J.T. and Craig A.M. (2001) Correlation of ergovaline and lolitrem B levels in endophyte-infected perennial ryegrass (Lolium perenne). Journal of Veterinary Diagnostic Investigation, 13, 323-327.

ISSELSTEIN J. (2005) Enhancing grassland biodiversity and ist consequences for grassland management and utilisation. In: McGilloway D.A. (ed.) Grassland: a global resource. Wageningen Academic Publishers, 2005, 305-320.

Jensen A.M.D. and RouLund N. (2004) Occurrence of neotyphodium endophytes in permanent grassland with perennial ryegrass (lolium perenne) in denmark. Agriculture, Ecosystems \& Environment, 104, 419-427.

Joost R.E. (1995) Acremonium in fescue and ryegrass: boon or bane? A review. Journal of Animal Science, 73, 881-888.

Khayamim F., Khademi H. and Sabzalian M. (2010). Effect of Neotyphodium endophyte-tall fescue symbiosison mineralogical changes in clay-sized phlogopite and muscovite. Plant and Soil, 341, 473-484.

Klimek S., Richter G., Kemmermann A., Hofman M. and Isselstein J. (2007) Plant species richness and composition in managed grasslands: The relative importance of field management and environmental factors. Biological Conservation, 134, 559-570.

$\mathrm{KOH}$ S. and HIK D.S. (2007) Herbivory mediates grass-endophyte relationships. Ecology, 88, 2752-2757. 
LAtCh G., Hunt W.F. and Musgrave D.R. (1985) Endophytic fungi affect growth of perennial ryegrass. New Zealand Journal of Agricultural Research, 28, 165168.

LEUCHTMANN A. (1993) Systematics, distribution, and host specificity of grass endophytes. Natural Toxins, 1, 150-162.

LeWis G.C., Ravel C., NaffaA W., Astier C. and Charmet G. (1997) Occurrence of acremonium endophytes in wild populations of lolium spp. In european countries and a relationship between level of infection and climate in france. Annals of Applied Biology, 130, 227-238.

MALINOWSKI D.P. and BELESKY D.P. (2000) Adaptations of endophyte-infected coolseason grasses to environmental stresses: Mechanisms of drought and mineral stress tolerance. Crop Science, 40, 923-940.

MALINOWSKI D.P. and BELESKY D.P. (2006) Ecological importance of Neotyphodium spp. grass endophytes in agroecosystems. Grassland science, 52, 1.

OldenBuRg E. (1997) Endophytic fungi and alkaloid production in perennial ryegrass in germany. Grass and Forage Science, 52, 425-431.

Prestidge R.A., Pottinger R.P. and BARKer G.M. (1982) An association of Lolium endophyte with ryegrass resistance to Argentine stema weevil. Proceedings of the NZ weed and pest control conference, 35, 119-122.

SaAri S., Helander M., Lehtonen P., Wallius E. and Saikkonen K. (2010) Fungal endophytes reduce regrowth and affect competitiveness of meadow fescue in early succession of pastures. Grass and Forage Science, 65, 287-295.

SABZALIAN M. and MiRLOH A. (2010) Neotyphodium endophytes trigger salt resistance in tall and meadow fescues. Journal of plant nutrition and soil science, 173, 952-957.

SaikKonen K., Faeth S.H., Helander M. and Sullivan T.J. (1998) Fungal endophytes: A continuum of interactions with host plants. Annual Review of Ecology and Systematics, 29, 319-343.

Saona N.M., Albrectsen B.R., ERicson L. and Bazely D.R. (2010) Environmental stresses mediate endophyte-grass interactions in a boreal archipelago. Journal of Ecology, 98, 470-479.

SHELBY R.A. and DALRYMPLE L.W. (1993) Long-term changes of endophyte infection in tall fescue stands. Grass and Forage Science, 48, 356-361. 
THOMPSON J.N. (1994) The coevolutionary process, University of Chicago Press, Chicago.

VAN SANTEN E. (1992) Animal preference of tall fescue during reproductive growth in the spring. Agronomy journal, 84, 979.

Weibull A.-C., Östman Ö. and GranqVist A. (2003) Species richness in agroecosystems: the effect of landscape, habitat and farm management. Biodiversity and Conservation, 12, 1335-1355.

WenNSTRÖm A. (1994) Endophyte - The misuse of an old term. Oikos, 71, 535-536. WHITE J.F. (1997) Systematics of the graminicolous clavicipitaceae: applications of morphological and molecular approaches. In: Bacon C.W. and Hill N.S. (eds.) Neotyphodium/Grass interactions. Plenum Press, New York, 1997, 27-39.

WILKINSON H.H. and SCHARDL C.L. (1997) The evolution of mutualism in grassendophyte associations. In: Bacon C.W. and Hill N.S. (eds.) Neotyphodium/Grass interactions. Plenum Press, New York, 1997, 13-25.

WILSON D. (1995) Endophyte - the evolution of a term, and clarification of its use and definition. Oikos, 73, 274-276.

ZabalgogeazcoA I. and Bony S. (2008). Neotyphodium Research and Application in Europe. In: Roberts C.A., West, C.P. and Spiers D.E (eds.) Neotyphodium in cool-season grasses. Blackwell Publishing Ltd., Ames, lowa, USA, 2005, 23-33.

Zabalgogeazcoa I., De Aldana B.R.V., Ciudad A.G. and Criado B.G. (2003) Fungal endophytes in grasses from semi-arid permanent grasslands of western spain. Grass and Forage Science, 58, 94-97. 


\section{Publications}

\section{Articles}

Dobrindt L., Stroh H.-G., Isselstein J. and VidAL S. (2011) Infected - not infected: Factors influencing the abundance of the endophyte Neotyphodium lolii in managed grasslands. (In preparation for submission)

DOBRINDT L. and VIDAL S. (2011) Influence of grassland management on the abundance of the endophytic fungus Neotyphodium in a permanent grassland. (In preparation for submission)

Dobrindt L., CUCHILlo M. and VIDAL S. (2011) Influence of grazer species and sward diversity on the abundance of the endophytic fungus Neotyphodium does plant diversity matter? (In preparation for submission)

Valdez N., Karlovsky P., Dobrindt L., Tantau H. and Muehlbach H.-P. (2011) The role of bacteria in dieback disease of Dalbergia sissoo. (In preparation for submission)

\section{Presentations at conferences or workshops}

DOBRINDT L. and VIDAL S. (2009) Influence of an endophytic fungus on plantherbivore-parasitoid interactions. Deutsche Gesellschaft für allgemeine und angewandte Entomologie, Göttingen, Germany

\section{Posters at conferences or workshops}

DoBrindt L., ALKHEDIR H., HAHN H. and VIDAL S. (2009) Do aphids serve as vectors for systemic grass endophytes? Deutsche Gesellschaft für allgemeine und angewandte Entomologie, Göttingen, Germany.

DOBRINDT L. and VIDAL S. (2011) Influence of livestock co-grazing on the abundance of the endophytic fungus Neotyphodium - Does plant diversity matter? International conference "Functions and services of biodiversity" 20.-22.6.2011, Göttingen, Germany. 


\section{Acknowledgements/ Danksagungen}

Prof. Dr. Stefan Vidal danke ich für das interessante Thema, für den Freiraum, für das Vertrauen und die Unterstützung, für die anregenden Diskussionen und für die hilfreiche Durchsicht der Manuskripte.

Ich danke Prof. Dr. Johannes Isselstein für die bereitwillige Übernahme des Korreferats, für die hilfreichen Diskussionen und die wertvollen Hinweise bei der Fertigstellung des ersten Manuskriptes.

Hans-Georg Stroh danke ich für die gute und sehr hilfreiche Kooperation.

Bei Dr. Christoph Scherber bedanke ich mich ganz herzlich für seine Unterstützung bei der statistischen Auswertung.

Dr. Nayuf Valdez danke ich für die guten Ratschläge in allen molekularen und auch sonstigen Fragen und für ihre Hilfe bei der Optimierung der PCR.

Bei Isabella Herwig bedanke ich mich für ihre Hilfe bei der Bearbeitung der Grasproben.

Ich danke den Landwirten in der Region Northeim für ihre Kooperation und die Erlaubnis ihre Flächen zu beproben.

Meinen Freunden und Kollegen danke ich für ihr offenes Ohr, für ihre Hilfe und für die schöne gemeinsame Zeit.

Meinem Ehemann Dr. Mike Dobrindt danke ich für seine unendliche Unterstützung, für all die Liebe und für das Lachen! 


\section{Curriculum vitae}

\section{Studium:}

seit $04 / 2008$

Promotionsstipendium im Rahmen des „Functional Biodiversity Research“-Exzellenzclusters in der Abteilung "Agrarentomologie“

04/2007 - 02/2008 Diplomarbeit in der Abteilung „Agrarentomologie“ an der „Georg- August Universität Göttingen“ zum Thema: „Einfluss eines endophytischen Pilzes auf Pflanze-Herbivor-Parasitoid Interaktionen."

26/01/2007 Diplomprüfung

seit 10/2004 Hauptstudium Biologie Diplom an der „Georg-August-

Universität Göttingen“

Hauptfach: Botanik

Nebenfächer: Phytomedizin, Mikrobiologie

10/2002 - 7/2004 Grundstudium

\section{Praktika:}

01/02/2006-15/04/2006 Referat für Presse- und Öffentlichkeitsarbeit der Max- Planck-Gesellschaft, München

12/12/2005 - 27/01/2006 "Georg-August- Universität Göttingen“, Agrarentomologie

22/08/2005 - 30/11/2005 Bertelsmann Stiftung „Qualifizierungsprogramm Wissenschaftsjournalismus“, Gütersloh

26/07/2004 - 20/08/2004 IWF Wissen und Medien gGmbH: Abteilung „Öffentlichkeit und Marketing“

Tätigkeiten als studentische Hilfskraft:

15/08/2006 - 30/09/2007 Max-Planck-Institut für biophysikalische Chemie, Abteilung "Massenspektrometrie“

21/07/2003 - 17/08/2003 „Ethologische Station Sennickerode“: Verhaltensforschung und Tierpflege bei Weißbüschelaffen

Schulausbildung:

08/1995 - 06/2002: „Europaschule Theodor-Heuss- Gymnasium”, Göttingen

\section{Ehrenamtliches Engagement:}

seit 11/2009

$11 / 2008-11 / 2009$
Doktorandensprecherin des Instituts für Pflanzenpathologie und Pflanzenschutz an der "Georg-August-Universität" Göttingen Stellvertretende Doktorandensprecherin 


\section{Eidesstattliche Erklärung}

Hiermit erkläre ich eidesstattlich, dass diese Dissertation selbständig und ohne unerlaubte Hilfe angefertigt wurde.

Göttingen, September 2011 